\title{
Reforestation and land use change as drivers for a decrease of avalanche damage in mid-latitude mountains (NW Spain)
}

\author{
Cristina García-Hernández ${ }^{\mathrm{a}, *}$, Jesús Ruiz-Fernández ${ }^{\mathrm{a}}$, Covadonga Sánchez-Posada $^{\mathrm{b}}$, \\ Susana Pereira $^{\mathrm{c}}$, Marc Oliva ${ }^{\mathrm{c}}$, Gonçalo Vieira ${ }^{\mathrm{c}}$ \\ a Department of Geography, University of Oviedo, C/ Amparo Pedregal s/n, 33011 Oviedo, Spain \\ b Department of Statistics, Operational Research and Mathematics Didactics, University of Oviedo, Calvo Sotelo $s / n, 33007$ Oviedo, Spain \\ ${ }^{c}$ Centre for Geographical Studies, Institute of Geography and Spatial Planning, Universidade de Lisboa, R. Branca Edmée Marques, 1600-276 Lisboa, Portugal
}

\section{A R T I C L E I N F O}

\section{Keywords:}

Snow avalanches

Deforestation

Reforestation

Land-use change

Damage index

Cantabrian Mountains

\begin{abstract}
A B S T R A C T
Natural conditions that explain the triggering of snow avalanches are becoming better-known, but our understanding of how socio-environmental changes can influence the occurrence of damaging avalanches is still limited. This study analyses the evolution of snow avalanche damage in the Asturian Massif (NW Spain) between 1800 and 2015, paying special attention to changes in land-use and land-cover patterns. A damage index has been performed using historical sources, photointerpretation and fieldwork-based data, which were introduced in a GIS and processed by means of statistical analysis. Mapping allowed connecting spatiotemporal variations of damage and changes in human-environment interactions. The total number of victims was 342 (192 dead and 150 injured). Results show stability in the number of avalanches during the study period, but a progressive decrease in the damage per avalanche. Changes in land use explain the evolution of damage and its spatial/temporal behaviour. The role played by vegetation cover is at the root of this process: damage was the highest during the late 19th and early 20th centuries, when a massive deforestation process affected the protective forest. This deforestation was the result of demographic growth and intensive grazing, disentailment laws and emerging coal mining. Since the mid-20th century, the transformation of a traditional landmanagement system based on overexploitation into a system based on land marginalization and reforestation, together with the decline of deforestation due to industrial and legal causes, resulted in the decrease of avalanches that affected settlements (mostly those released below the potential timberline). The decrease of damage has been sharper in the western sector of the Asturian Massif, where oak deforestation was very intense in the past and where lithology allows for a more successful ecological succession at present. Taking into account that reforestation can be observed in mountain environments of developed countries worldwide, and considering present initiatives conducted to counteract its negative cultural effects by means of grazing and clearing operations, planning is imperative, and this research provides useful information for environmental management policies and risk mitigation in avalanche prone areas.
\end{abstract}

\section{Introduction}

Snow avalanches are a major slope process in mountain environments, posing a significant threat in the coolest and highest regions of the world (Schneebeli et al., 1997; Johannesson and Arnalds, 2001; Fuchs et al., 2004; Keiler et al., 2005; Podolskiy et al., 2014). In the mountain environments of the Iberian Peninsula, snow avalanches are frequent; the Pyrenees, Cantabrian Mountains and Central Range are periodically affected by this kind of events (Mases and Vilaplana, 1991; Furdada et al., 1995; Julián and Chueca, 1999; Muntán et al., 2009; Fernández-Cañadas et al., 2015). In the Cantabrian Mountains only a few studies have addressed this issue (Castañón, 1984; Wozniak and Marquínez, 2004; Santos-González et al., 2010; Vada et al., 2012; García-Hernández et al., 2014; Serrano et al., 2016). This poor understanding of avalanches and their triggering factors is particularly significant in the case of the Asturian Massif, the highest and largest sector of Cantabrian Mountains, where this research focuses.

The consequences of hazards are usually evaluated taking into account the degree of loss or the level of damage derived from a specific hazard (UNISDR, 2009) that can be estimated in terms of monetary units or social values, accounting the number of dead and injured people (Alexander, 1996), affected buildings (Merz et al., 2004) or

\footnotetext{
* Corresponding author.

E-mail address: cristingar@hotmail.com (C. García-Hernández).
} 
infrastructures (Geertsema et al., 2009), or using a synthetic index to quantify personal injuries, damages to property and disruptions of economic activities (Fekete, 2009; Pereira et al., 2016). Only a few studies have specifically quantified the effects of changes in population, exposure of people and assets, and vulnerability as determinants of loss (IPCC, 2012). In addition, since exposure and vulnerability vary over time and space depending on economic, social, geographic, demographic, cultural, institutional, governance and environmental factors (IPCC, 2012), if we want to understand the dynamics of natural hazards, we must analyse how human and natural systems interact in the long-term (Mileti and Myers, 1997). Measuring the degree of influence that human-induced modifications have on damage ratio of events may provide a better prediction on future effects of these modifications on the natural systems. Moreover, not only avalanche risk, but exposure to that risk, is variable in time due to transformations affecting the human system and its links to the natural system, such as changes in land use and social vulnerability of inhabitants (Fuchs et al., 2005; Keiler et al., 2005). In this sense, it is important to emphasize the importance that induced changes on vegetation cover, as a consequence of land use changes, could have on the increase of the avalanche risk (Gubler and Rychetnik, 1991).

The development of natural hazard databases is decisive for risk management because they allow identifying the relationships between the occurrence of dangerous natural phenomena and the existence of exposed and vulnerable population. Such databases also enable a quick access to data that can be analysed using the most recent advances in geostatistical and modelling techniques providing avenues for risk mitigation. Historical documents have been increasingly employed in natural hazard research (Pfister et al., 2006; Raška et al., 2014; Pereira et al., 2016) and several research studies have stressed the potential use of documentary data sources to reinforce the knowledge on snow avalanche events, illustrating the strong interaction between economic and social development and snow avalanche activity (Irwin and Owens, 2004; Hétu et al., 2011; Podolskiy et al., 2014; Hétu et al., 2015). Since the beginning of the 21st century, policies for disaster risk reduction have shifted from structural mitigation measures to a more comprehensive and integrated approach in which mapping is an essential tool for better understanding natural disaster dynamics (EEA, 2010). Geographical location and extent of hazards serve the purposes of associating reported impacts with socio-economic and environmental contextual parameters (Peduzzi et al., 2005). Thus, hazard mapping is essential in order to assess the causes and consequences of natural disasters, and it provides a solid basis for rational land-use planning (Kienholz, 1978).

The purposes of this paper are to: i) Map and analyse the spatial and temporal distribution of snow avalanches, as well as its level of damage in the Asturian Massif from 1800 to 2015; ii) Examine temporal variability of the damage as a result of changes on the interactions between human and natural systems; iii) Identify the key factors explaining the occurrence of damaging avalanches or influencing its consequences; iv) Assess, in particular, how induced changes in vegetation cover from changes in land uses, could have influenced the variation of damage over time.

\section{Study area}

The Asturian Massif (Fig. 1) makes up the western area of the Cantabrian Mountains, located in the NW of the Iberian Peninsula. This massif is essentially composed of sedimentary and metamorphic rocks from the Palaeozoic Era, folded and/or fractured by two orogenies, the Hercynian and the Alpine (Julivert, 1983; Martínez-Catalán et al., 1992). The lithology is very mixed, showing a predominance of siliceous materials (mainly sandstone, slate and quartzite) in the western part of the massif, and an alternation of calcareous and siliceous sedimentary rocks in the central and eastern parts. The Picos de Europa, one of the main limestone massifs in the world (Ruiz-
Fernández et al., 2016), is located in the latter part.

The topography of the Asturian Massif shows a substantial northsouth dissymmetry, with considerably steeper and sharper descents in the northern slope. Its highest areas generally exceed $2000 \mathrm{~m}$, and the highest altitudes are reached in the Picos de Europa (Torrecerredo, $2648 \mathrm{~m}$ ). Also, this massif contains a wide surface developing above $1500 \mathrm{~m}$, as well as numerous upland areas between 1000 and $1500 \mathrm{~m}$. Therefore, this mountain area is characterised by the existence of large altimetric differences, very enclosed valleys and rather steep hillsides.

The northern slope of the Asturian Massif is characterised by an oceanic climate, with mild average temperatures (between $10{ }^{\circ} \mathrm{C}$ and $14{ }^{\circ} \mathrm{C}$ ), and heavy rains (between 1400 and $1500 \mathrm{~mm}$ annually in general, and even $>2000 \mathrm{~mm}$ annually in the highest areas) spread evenly throughout the year (Muñoz-Jiménez, 1982). Conversely, the southern slope has a transitional oceanic-Mediterranean climate, characterised by annual average temperatures below $10^{\circ} \mathrm{C}$, rains exceeding $1000 \mathrm{~mm}$ in the highest areas only, and summer dryness for one or two months. This moderate and mostly humid climate allows the development of Atlantic deciduous forests where the natural tree line is placed at $1600 \mathrm{~m}$ a.s.l. on average (Ruiz-Fernández et al., 2008), 1450/1650 m a.s.l. in the northern slopes and 1700/1850 $\mathrm{m}$ a.s.l. in the southern aspect (Muñoz-Sobrino et al., 2012).

Human presence in the mountainous areas of the Asturian Massif has been traditionally connected with livestock farming (Suárez et al., 2005), which has contributed to the mobility of human groups between the higher and lower areas of the massif, and between its northern and southern slopes through mountain passes. Numerous infrastructures can be seen in these areas, the construction of which experienced a substantial increase from 1850 on. Historically, the mountainous villages of the Asturian Massif have been isolated and densely populated, which enhanced the potential damages of avalanches to people and property. Although recent socioeconomic changes have led to a lower demographic pressure in most of the highest inhabited lands, there has been a parallel improvement of the road network which has brought more visitors to the highest areas of the massif, where the avalanche hazard is more noticeable. Therefore, in this massif, the potential for damage to recreation and transport during the cold season is remarkable and, even though it has caused large socio-economic damages, the history of snow avalanche accidents has not been reconstructed.

\section{Materials and methods}

\subsection{Obtaining the data}

The compilation of the data series of avalanches that occurred between 1800 and 2015 has been carried out examining historical sources, such as newspapers and church documents. For the former, we have analysed 32 newspapers at the regional and national level covering the period under analysis. From these, 891 issues were manually surveyed focusing on the news published between the months of November and April, which reflects the snow season. The sources were the hardcopy microfilms from the Central Library of Asturias and the National Library of Spain. Further 3208 issues have been examined through virtual newspaper libraries using the Spanish key-words "avalancha" (avalanche) and "alud de nieve" (snow mass movement). The procedure resulted in the identification of 273 news related with snow avalanches in the Asturian Massif. The wide criteria used to select the news aimed at guaranteeing a wide spatial distribution and to avoid gaps. Moreover, we have examined the records of church documents (records of deceased people) from 62 mountain parishes across the Asturian Massif. These documents, written between 1800 and 1960, allowed identifying other 18 damaging events which had not been reported in newspapers, resulting in a total of 291 events.

The paths of 126 of these avalanches were reconstructed in the field through geomorphological evidence and testimonies of residents and 


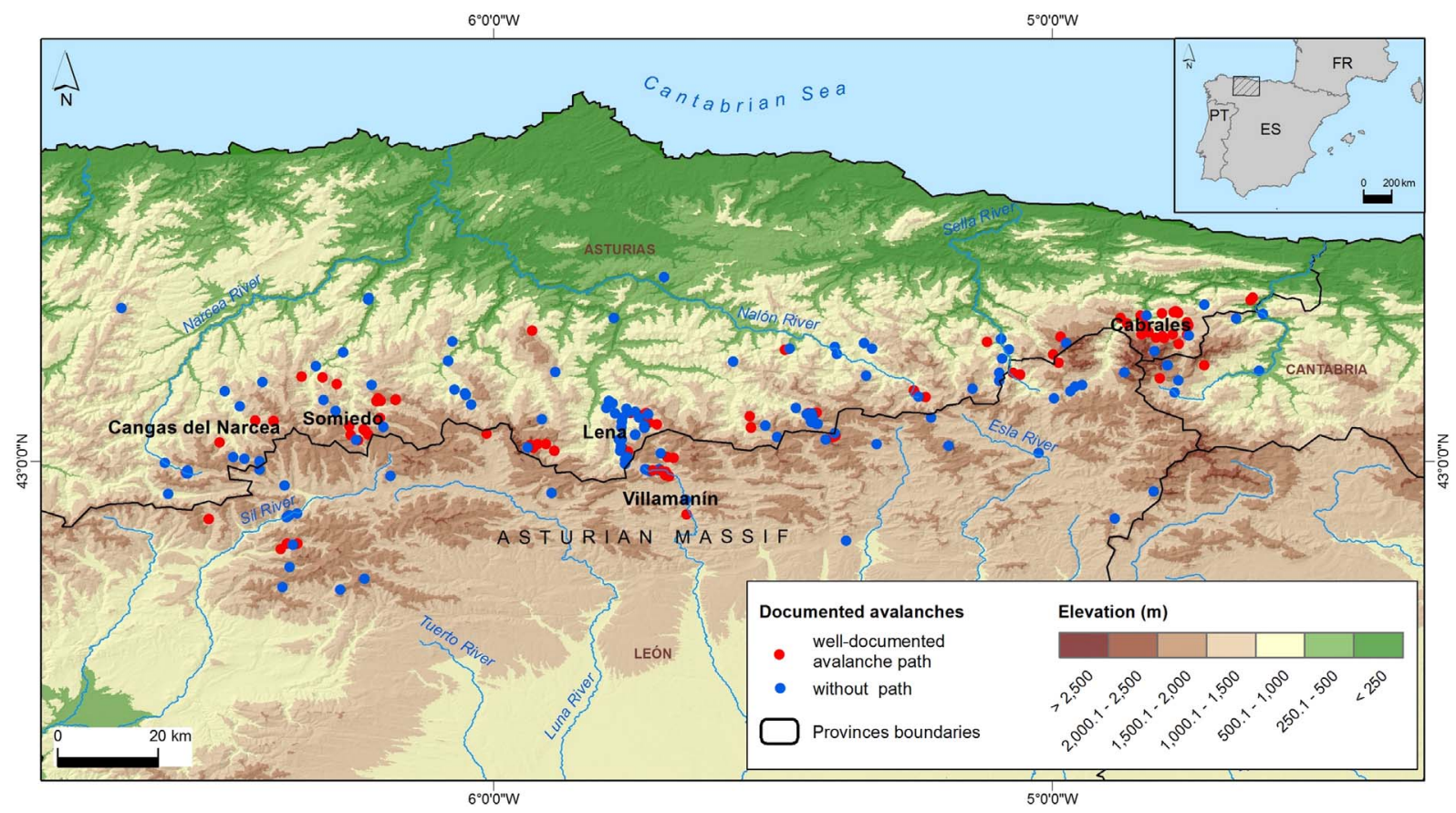

Fig. 1. Location of the study area and the sites mentioned along the text.

witnesses. The criterion for selecting these 126 avalanches was good data availability. The analysis of present vegetation formations colonising the starting areas was conducted by means of photo-interpretation and fieldwork (as a way to verify the findings of the photointerpretation). Four categories of vegetation cover were assessed: forest, shrubland, grassland, sparse vegetation. We have also used aerial photography, ancient photographs and prints to support field observations.

\subsection{Conducting the geostatistical analysis}

Data on avalanche location, characteristics and consequent damages were stored in a database management system in order to facilitate the subsequent statistical analysis. All 291 historical avalanches were introduced in a GIS with a point in the geometric centroid of the depletion area. The analysis was based on a high resolution Digital Elevation Model (MDT05 of the Spanish National Geographic Institute, with a $5 \mathrm{~m}$ grid size). The boundaries of the 126 events with welldocumented avalanche path were drawn as polygons (depletion, transportation and accumulation areas). For each avalanche, data on place and date of occurrence, together with information about people and affected structures, were also compiled. Besides, regarding the 126 avalanches with a well-documented avalanche path, we also collected and analysed data referring to the starting point (aspect and release angle $\theta$ ), average angle over the run of the avalanche $(\alpha)$, and distance to the impact point with people or structures.

For data processing and figures, we have used the free software environment R. Statistical analysis has been performed through classical descriptive statistics and several techniques of robust statistics: median, 25th and 75th percentiles as measures of central tendency; interquartile range as a measure of spread; winsorised means; Tukey's method instead of classic method of mean $\pm 3 *$ standard deviation. These types of techniques prevent results from being affected by outliers. Tukey's method (Tukey, 1977) has been used for outlier detection, characterizing extreme values of the distribution as "high" (Eq. 1) or "far high" (Eq.2):

High $=75$ thPercentile $(\mathrm{P} 75)+1.5 *$ IntercuartileRange $(\mathrm{IQR})$

Far-high $=\mathrm{P} 75+3^{*} \mathrm{IQR}$

We made use of statistical inference to detect statistically significant differences between groups. Parametric techniques (the Student's $t$-test, and non-parametric methods as the Wilcoxon rank-sum test) have been employed as well.

\subsection{Calculating a damage index}

To assess the evolution of the damage resulting from avalanche activity, a damage index has been performed. These kinds of indices are indirect numerical surrogates of phenomena (Fekete, 2009) that allow for quantifying numerically the damage. To calculate the index we have considered eight dimensions of damage that have been incorporated into two components: the personal and the material damage (PD and $\mathrm{MD})$. These two components have been synthesised on a total damage (TD) index, depending on Eq. 3:

$\mathrm{TD}=0.8 * \mathrm{PD}+0.2 * \mathrm{MD}$

PD and MD depend on the weight of their related dimensions (Table 1). These dimensions have been selected and weighted using as reference framework specific criteria used by reinsurers and institutions such as the Munich Reinsurance Company and the Centre for Research on the Epidemiology of Disasters (Below et al., 2009). When any of the conditions exposed in Table 1 is fulfilled, the avalanche is considered to be damaging.

Table 1

PD and MD dimensions and corresponding assigned weight used to obtain TD index.

\begin{tabular}{llll}
\hline Dimensions of damage & Assigned weight & & \\
\hline Dead & 4 & $80 \%$ & PD \\
Injured & 2 & & \\
Homeless & 1 & & MD \\
& & & \\
Home & 4 & $20 \%$ & \\
Train Building & 3 & & \\
Infrastructure & 2 & & \\
Head of cattle & 2 & & \\
Road vehicle & 1 & & \\
Road/railroad outage & 1 & & \\
Forest disturbance & 1 & & \\
\end{tabular}




\subsection{Spatial and temporal analysis}

The study period (1800-2015) has been divided in three welldefined stages in the territorial dynamics of the Asturian Massif: 1800-1899 (rural), 1900-1959 (mostly rural with early urban industrialization) and 1960-2015 (rural abandonment with gradual tourism increase) (García-Fernández, 1980; Ortega-Valcárcel, 1989; FernándezGarcía, 2006; Rodríguez-Pascual, 2006). These stages are used to explain damage index shifts over time, establishing connections with socio-economic, demographic and environmental changes. The territory was divided into three sectors (Western, Central and Eastern), in order to analyse those causes of index evolution related to the different territorial dynamics across the massif. Moreover, we established four typologies of land use affecting the avalanche areas in the moment of the events (settlements, agro-silvo-pastoral, road or railroad, recreational).

\subsection{Connecting the damage index with social factors}

In order to eliminate the effect that population oscillations could have on the evolution of the index, we examined the evolution of the number of fatalities (parameter with the greatest weight in the calculation of the TD index) per 100,000 inhabitants, compared with the evolution of the number of avalanches. For the population analysis we used data since 1870 s for five mountain municipalities regularly affected by avalanches (Somiedo, Cangas del Narcea, Lena, Villamanín and Cabrales) (Fig. 1). These municipalities summed $59 \%$ of the avalanches, $50 \%$ of the victims and $57 \%$ of TD, and its economic and demographic dynamics are uniform. This population sample was used as a measure of the inhabitants exposed to avalanche hazard.

Finally, the main processes considered in the discussion have been included in a timeline (Fig. 17), to connect them with the evolution of the TD index. A base-1 log scale has been used in order to represent those processes in the same scale, enabling the evaluation of their evolution with regard to their own highest and lowest values over time. Sources used to perform this timeline have been the Statistical Yearbook 1858-2015, National Forest Inventory 1966-2007, Mining Statistics of Spain 1861-2010, Asturian Society of Economic and Industrial Studies and Spanish Statistical Office.

\section{Results}

\subsection{Evolution of the number of the damaging avalanches}

A total of 291 damaging avalanches were documented for the period 1800 to 2015. No decreasing trend is detected in the number of avalanches by stages (Fig. 2A). In fact, the stage 1960-2015 recorded the highest percentage of years with damaging avalanches (48\%) as well as the highest percentage of years recording more than five events (13\%) (Fig. 2B).

\subsection{Avalanche-related damages evolution}

The total number of victims was 342 (192 dead, 150 injured), with the maximum concentration reached during the stage 1800-1899 (100 dead, 62 injured) and dramatically declining in the last stage 1960-2015 (20 dead, 50 injured) (Fig. 3A). Between the two first stages there is no substantial difference in the survival rate, which remains at around $38 \%$. The remarkable change is observed during the last stage, when the survival rate reaches $66 \%$ (Fig. 3B).

Regarding the number of victims, a decreasing trend over time is observed (Fig. 4). The western sector of the Asturian Massif encompasses $37 \%$ of the total victims, the eastern $36 \%$ and the central $27 \%$. The distribution of these percentages vary across the three stages, with a clear decline in the western sector (49-38-7\%) and increases in the central (29-23-43\%) and especially in eastern areas (22-39-50\%).A progressive decrease of the index of average damage per avalanche is detected. According to Student's $t$-test ( $p$-values $<0.0001$, in both cases), the differences in the averages are significant between the first and second and, also, between the second and third stages (Fig. 5A and $B)$. These differences have been confirmed by the Wilcoxon rank-sum test ( $p$-values $<0.0001$ and 0.0007 ), which also shows a staggered decrease by stages of the TD index, as observed in the Fig. 2A.Using the criteria of Tukey to analyse the annual aggregate of avalanches events, the number of deaths, number of victims, number of victims per 100,000 inhabitants and number of deaths per 100,000 inhabitants, we defined two types of outlier years: years far-high and high (Table 2). Outlier years concerning fatalities and victims are concentrated in the first stage, except for 1910. From 1910 onwards no atypical far-high year is recorded, with the exception of 2015, which recorded a large number of avalanches.

The normalised values of the number of avalanches per municipality's area are larger in the central sector of the Asturian Massif, with 0.085 events $/ \mathrm{km}^{2}$ ( 0.040 in the eastern and 0.020 in the western parts). The western sector concentrates $39 \%$ of the index, $30 \%$ the eastern and $31 \%$ the central. Spatial distribution of the number of avalanches and personal and material index values according to the total index values per municipality and stage are presented in Fig. 6A. A general decline of the TD is observed between the first stage (index value 1109) (Fig. 6B) and the third (210.4) (Fig. 6D), though the decrease is more pronounced in the western sector: it includes $46 \%$ of the index in the first stage but only $14 \%$ in the third, in the central part this trend is more moderated ( 35 vs. $28 \%$ ), while in the east is reversed (19 vs. $58 \%$ ). As for the percentage distribution of PD and MD, the PD is significantly
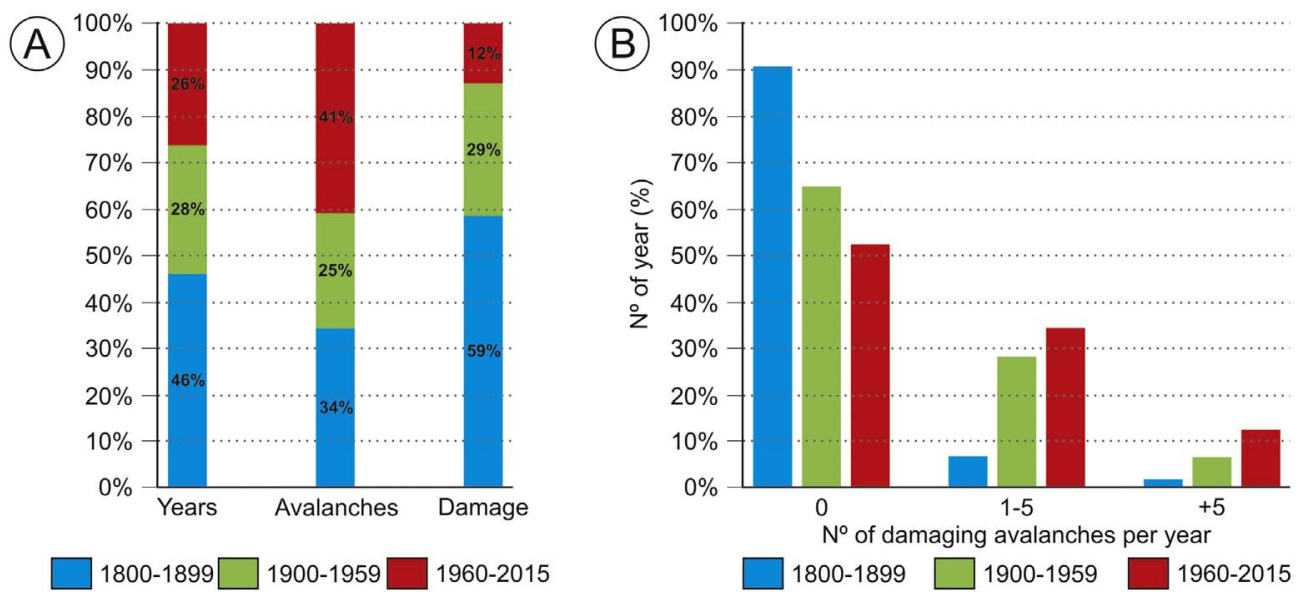

Fig. 2. (A) Percentage of years, avalanches and damage (TD index), per stage; (B) Percentage of years with zero, one to five and more than five damaging avalanches, per stage. 

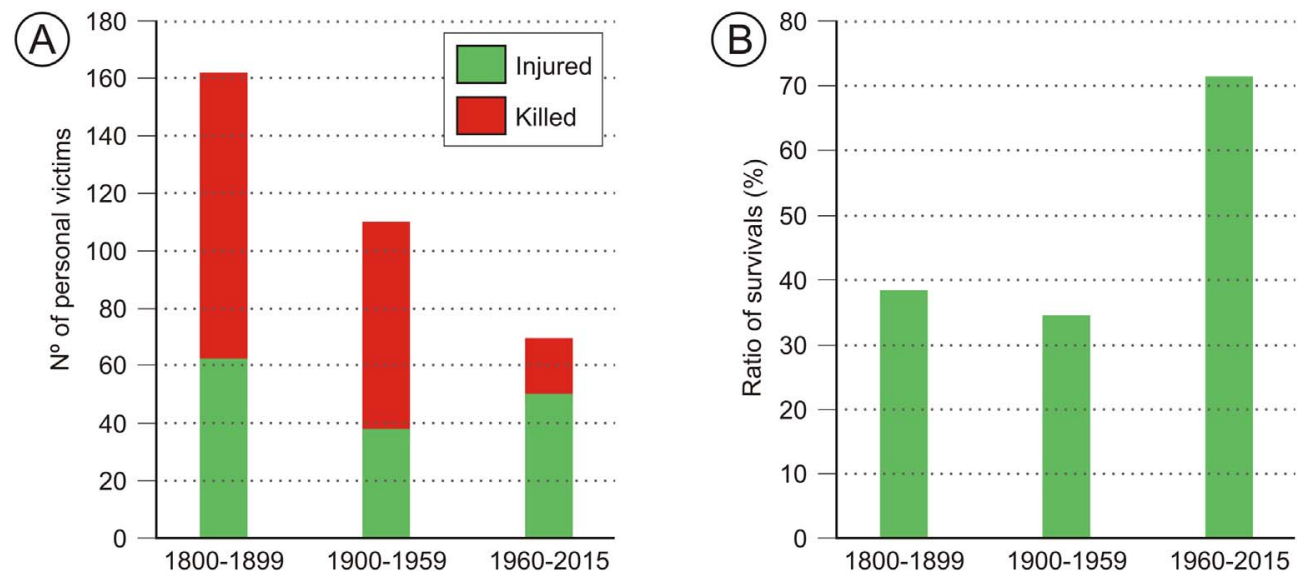

Fig. 3. (A) Number of personal victims (killed and injured) caused by damaging avalanches per stage; (B) ratio of survivals, per stage.

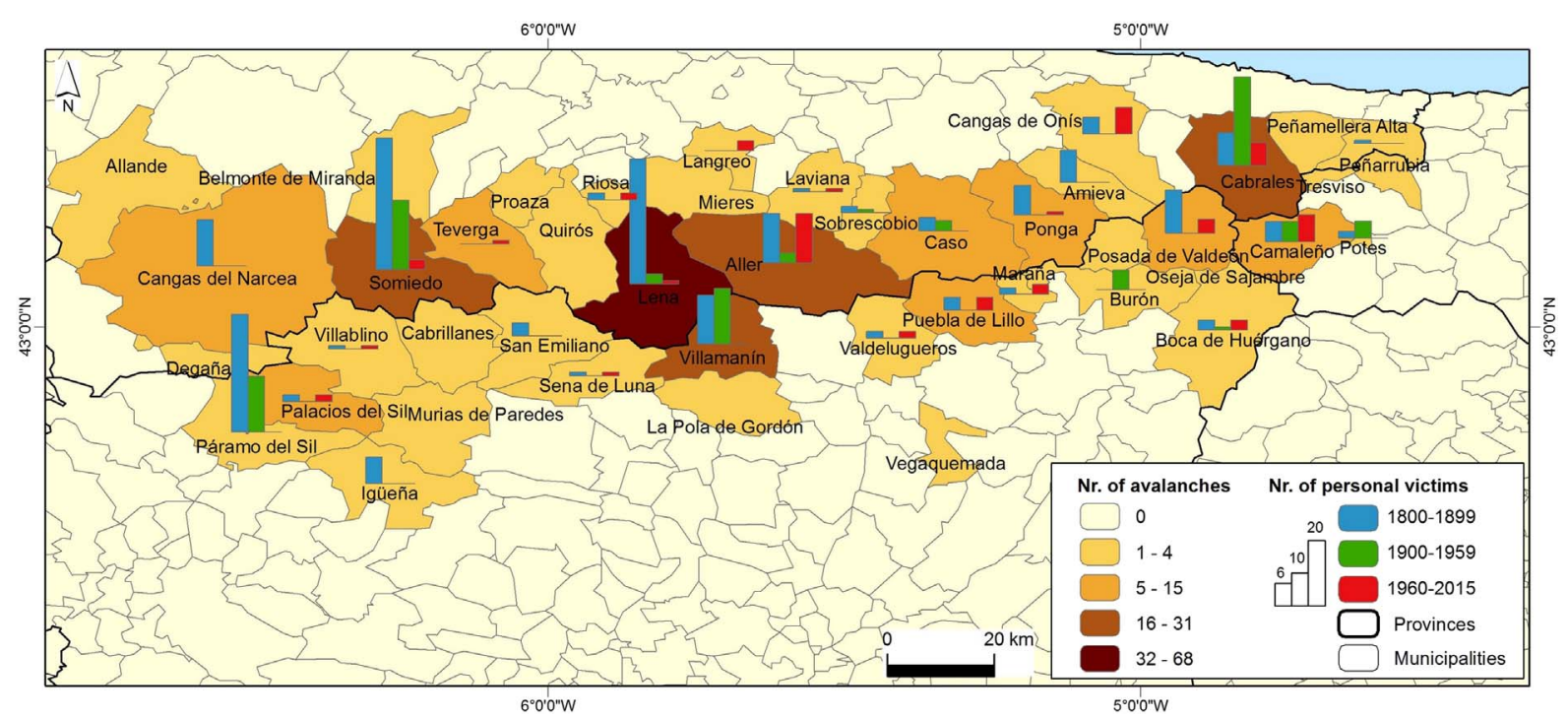

Fig. 4. Number of personal victims (killed and injured) per affected municipality and period and number of avalanches per municipality.

higher in the last stage, namely in the centre-east sectors (Fig. 6).

\subsection{Influence of environmental drivers and land-use on avalanche hazard}

Fig. 5A shows that the index of average damage per avalanche decreases significantly towards recent times, but this pattern is different if we consider the land use of the affected area at the time of the

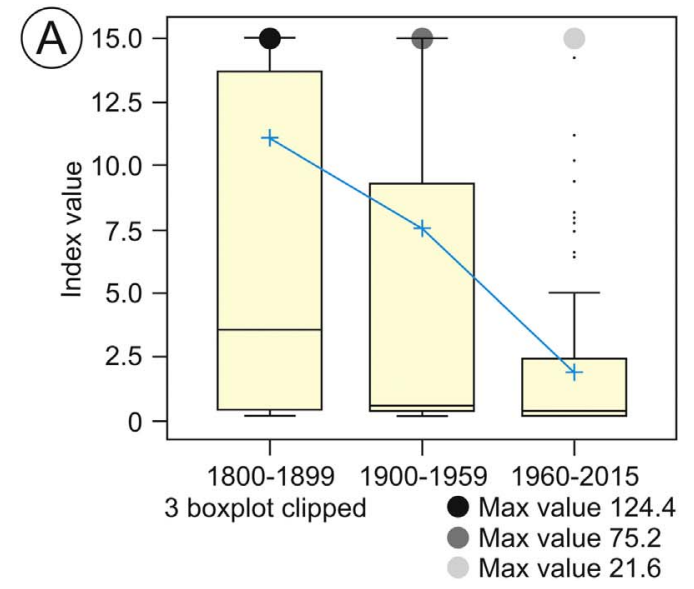

incident. TD index distribution according to the land use of the affected area during the three stages is presented in Fig. 7. This distribution shows an inverted "V" with further damage during the intermediate stage, or without significant differences between stages in the case of road and railroad typology.

Half of the avalanches has affected communication routes (Fig. 8A). However, if we look at the evolution of the phenomena over time, we

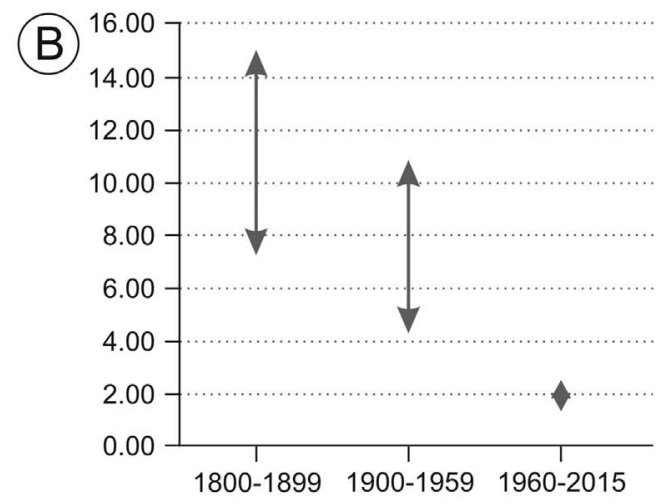

Fig. 5. (A) Distribution of TD index per avalache, per stage; (B) Confidence intervals at the $95 \%$ confidence level. 
Table 2

Outlier years concerning the annual aggregate of avalanche events, fatalities, personal victims (injured and killed), fatalities per 100,000 inhabitants, and personal victims per 100,000 inhabitants.

\begin{tabular}{llllll}
\hline Year & $\begin{array}{l}\text { Nr of } \\
\text { avalanches }\end{array}$ & $\begin{array}{l}\text { Nr of } \\
\text { victims }\end{array}$ & $\begin{array}{l}\text { Nr of } \\
\text { victims/ } \\
100.000 \\
\text { inh. }\end{array}$ & $\begin{array}{l}\text { Nr of } \\
\text { fatalities }\end{array}$ & $\begin{array}{l}\text { Nr of } \\
\text { fatalities/ } \\
100.000 \text { inh. }\end{array}$ \\
\hline 1857 & - & 20 & 13.1 & - & 4.6 \\
1871 & - & 27 & 17.3 & 19 & 12.2 \\
1888 & 67 & 60 & 33.3 & 28 & 15.6 \\
1895 & 19 & 24 & 13.3 & 18 & 10.0 \\
1910 & - & 28 & 13.2 & 17 & 8.0 \\
1935 & - & 17 & 6.6 & 8 & - \\
1945 & 14 & 16 & - & 8 & - \\
2005 & 17 & - & - & - & - \\
2015 & 25 & - & - & - & - \\
\hline
\end{tabular}

observe that the settlements have been the most affected land use during the first stage, while the road and railroad communication networks were the most disturbed after 1900, when settlements started to be less affected. During the third stage, between 1960 and 2015, the recreational category includes $19 \%$ of the damages generated by avalanches. The settlements are the spaces that concentrate more PD ( $68 \%$ of the index value throughout the study period) (Fig. 8B). This fact is more evident in the first stage, in which settlements recorded $>$ $80 \%$ of damage, subsequently descending until $21 \%$ of the damages produced during the last stage. Avalanches affecting recreational experienced the opposite trend, since they only appear in the last stage representing $35 \%$ of damage and the agro-silvo-pastoral category recorded its most remarkable peak in the stage of 1900-1959.The settlements concentrated the highest percentage of personal victims (49\%) and fatalities (59\%) (Fig. 9A, B) as well as the highest number of victims and fatalities per avalanche, and the lowest survival rate (Table 3). The recreational land use type concentrates less personal victims and fatalities, with the lowest number of victims and fatalities per avalanche, and the highest survival rate (Table 3).Using the criterion of Tukey to the distribution of the TD index, 36 extreme avalanches were detected. Settlements stand out as the space where $83 \%$ of these avalanches have impacted. Spatial distribution of the number of avalanches according to the land use of the affected areas by municipality and stage are represented in Fig. 10. Avalanches affecting the roads and railroads are the majority throughout the entire study period and for most of the territory, especially in the central part of the massif where they constitute $70 \%$ of the total (compared to $30-40 \%$ in the other sectors) (Fig. 10A). The avalanches affecting settlements represent $22 \%$ of those occurred in the eastern sector and $34 \%$ of the western sector, where this type of damaged space represents the higher percentage; however, $85 \%$ of avalanches in settlements in the western sector occurred in the first stage $77 \%$ in the central sector and $61 \%$ in the eastern) (Fig. 10b). Avalanches affecting the agro-silvo-pastoral space have been more numerous in the eastern and western areas $(28 \%$ and $22 \%$ of the total), while in the central part represent only $4 \%$ (Fig. 10A). Finally, avalanches affecting recreational areas, that only appear in the last stage, mainly occurred in the eastern part, where they represent $17 \%$ of the events (compared to $3-4 \%$ in the other areas) (Fig. 10D).

\subsection{Avalanche damage and population variation}

The evolution of the TD index is compared to population in Fig. 11. Variations of the TD index follow, with a slight gap, the same pattern of population: between 1874 and 1888 the population rose $18 \%$ and between 1888 and 1895 the index rose 20\%; between 1918 and 1931 the population grew by $27 \%$ and between 1931 and 1935 the index rose by $27 \%$. Similarly, when the population stabilizes and begins to fall, the index stagnates: between 1900s and 1960s the population grew by $60 \%$ and the index by $66 \%$, whereas between 1960 s and 2015 the population declined $66 \%$ and the index increased only by $7 \%$.

The evolution of the number of fatalities per 100,000 inhabitants, compared with the number of avalanches, shows that prior to 1870 the occurrence of fatalities was higher than the avalanches (Fig. 12). The growth followed a similar rate from 1870 until the 1960s, when the avalanche occurrences began to grow at a higher rate than the number of fatalities, which slowed down. This pattern is remarkable between 2000 and 2010, when the difference became more significant. While the growth rate of fatalities showed decreasing trends throughout the three stages $(49.7 \% ; 49.0 \% ; 14.2 \%)$, the growth rate of damaging avalanches show increasing trends (99.0\%; 121.7\%; 212.7\%), which suggests that the number of documented damaging avalanches is not reduced but, those avalanches, gradually, caused fewer fatalities.

\subsection{Spatial distribution of the avalanches and their consequences for damage}

The upper level of the dense forest in the Asturian Massif is located, on average, at $1600 \mathrm{~m}$ a.s.l. Regarding the 126 avalanches with a welldocumented avalanche path, $4 \%$ of avalanches were triggered and deposited above the timberline (AT), 33\% were triggered above the timberline and deposited below the timberline (AT-BT) and 63\% were triggered and deposited in the forest environment, below the timberline (BT). Up to $88 \%$ of AT avalanches took place from 1960 to 2015, while $70 \%$ of AT-BT and $75 \%$ of BT occurred before 1960 . AT concentrated $1 \%$ of the total damage, while AT-BT and BT included $46 \%$ and $53 \%$, respectively.

The average distance travelled until impacting the target was $932 \mathrm{~m}$, with a maximum of $2831 \mathrm{~m}$ and a minimum of $96 \mathrm{~m}$. There was a significant relationship (according to the Student's $t$-test) between distance and damage: the average TD of the avalanches travelling distances greater than P75 ( $>1375 \mathrm{~m}$ ) was 18.9; in the group that travelled medium distances, between P25 and P75 (476-1375 m) was 9.9, and in the smallest ones, travelling distances lower than P25 ( $<476 \mathrm{~m}$ ) was 3.2 (Fig. 13). Large avalanches occurred mainly during the first stage (41\%), showing the lowest proportion in the latter stage (24\%), while the rest of avalanches were distributed evenly over time. Up to $58 \%$ of the damage in settlements was due to BT avalanches $(28 \%$ to BT avalanches that started between 1400 and $1600 \mathrm{~m}$ ) and the impact of those small to medium avalanches releasing below the timberline was maximum (Table 4).

The vegetation colonising nowadays the release areas of the 126 avalanches with a well-documented avalanche path is shrubland in $34 \%$ of the cases, grassland in $25 \%$ and forest in $21 \%$ of the study cases. Another $20 \%$ of release areas present sparse vegetation. $50 \%$ of the forested release areas have not been functional since 1900 and up to $75 \%$ since the mid-1940s (Fig. 14A). Those avalanches which release area is now forested, are the oldest avalanches and they have the highest average damage rate (19) (Fig. 14B). The release areas colonized by sparse vegetation have been functional mostly during last stage (Fig. 14A) and show the lowest average damage rate (5) (Fig. 14B).With regards to the aspect of the release areas, the most frequent aspect was the southern, especially SW (28\%), with few events in northern aspects (Fig. 15A). The most damaging avalanches occurred in eastern-exposed slopes (average rate of 15\%), while the least damaging took place in western aspects (average rate of $8 \%$ ). Avalanches in southern aspects concentrate $61 \%$ of the index (Fig. 15B).If we split the avalanches in three groups depending on the distribution of TD (high, medium and low damage), we find that the damage increases as the angle $\alpha$ decreases (Fig. 16A). The average angle $\alpha$ in the high damage group was $29.4^{\circ}\left(31.4^{\circ}\right.$ in the medium damage group and $33.4^{\circ}$ in the low damage group). Up to $75 \%$ of avalanches of the high damage group occurred in slopes below $32^{\circ}$. This trend is attenuated for angles $\theta$ : the average angle $\theta$ in the high damage group was $33.6^{\circ}$, and in the 

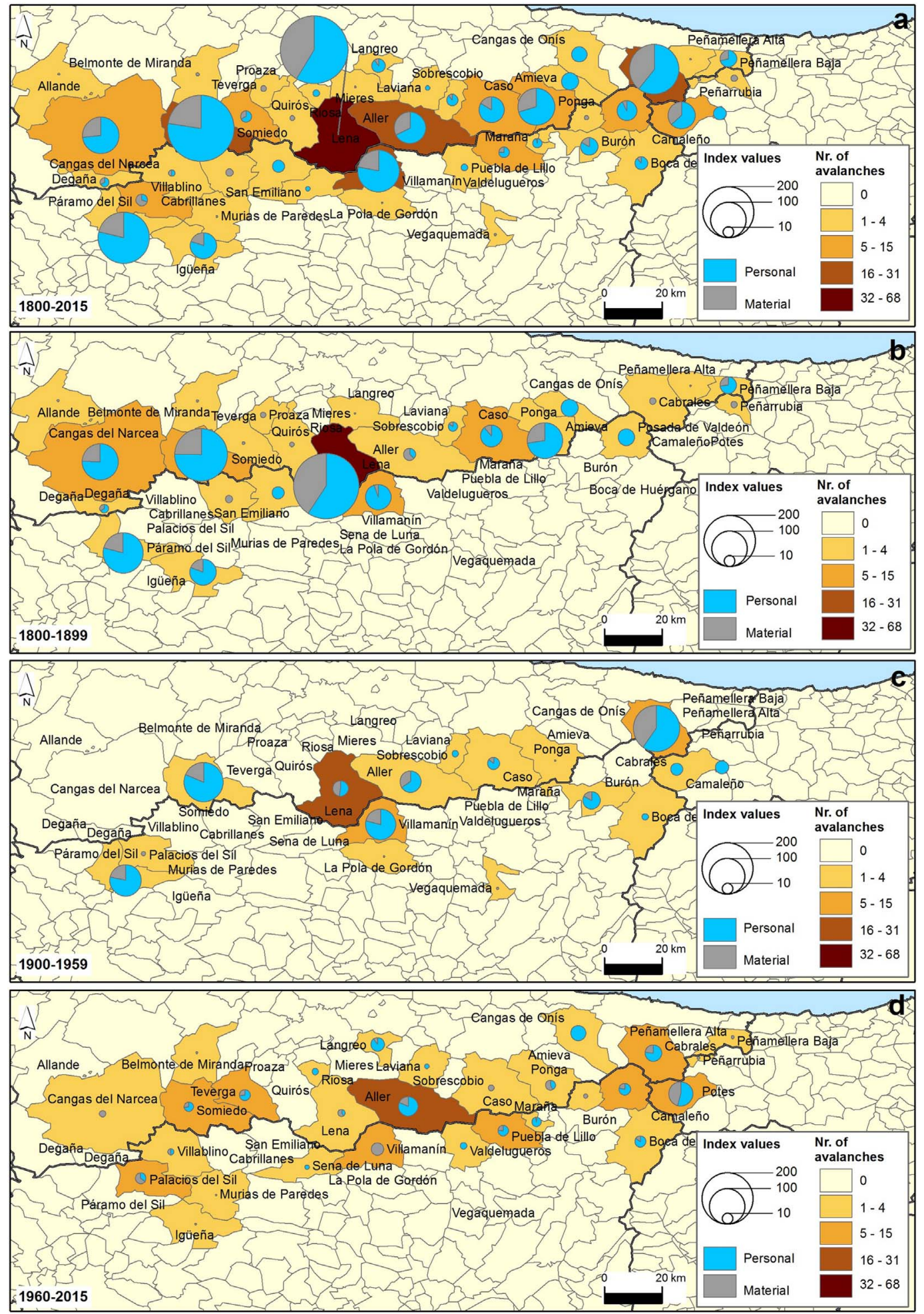

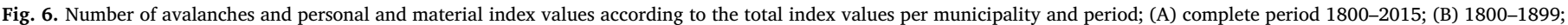
(C) 1900-1959; (D) 1960-2015.

case of the medium damage and low damage groups was $35.7^{\circ}$ (Fig. 16B). Both the angles $\alpha$ (average angle 29.5 ) as $\theta$ (average angle $32.7^{\circ}$ ) are lower in the settlements than in the rest of affected spaces (Fig. 16C, D).

\section{Discussion}

\subsection{Temporal evolution of the damaging avalanches}

While in mountains such as the Alps, the number of damaging avalanches has decreased over time due to significant mitigation efforts (Schneebeli et al., 1997; SLF, 2000; Fuchs et al., 2004), however, in the Asturian Massif, no decrease is observed per decade for the late 20th 


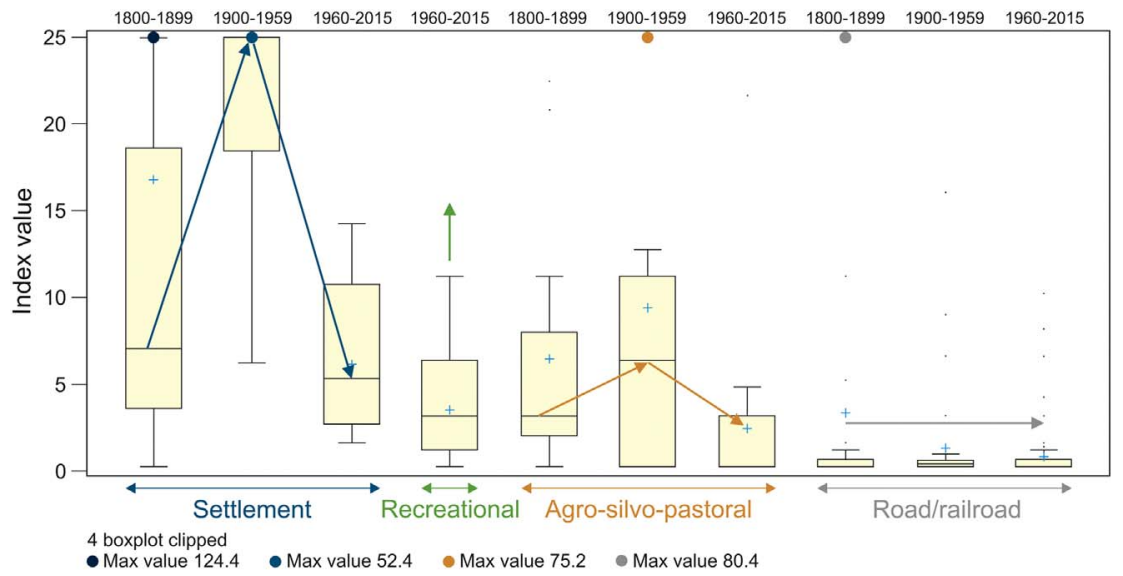

Fig. 7. TD index distribution according to the land use of the affected area, per stage.
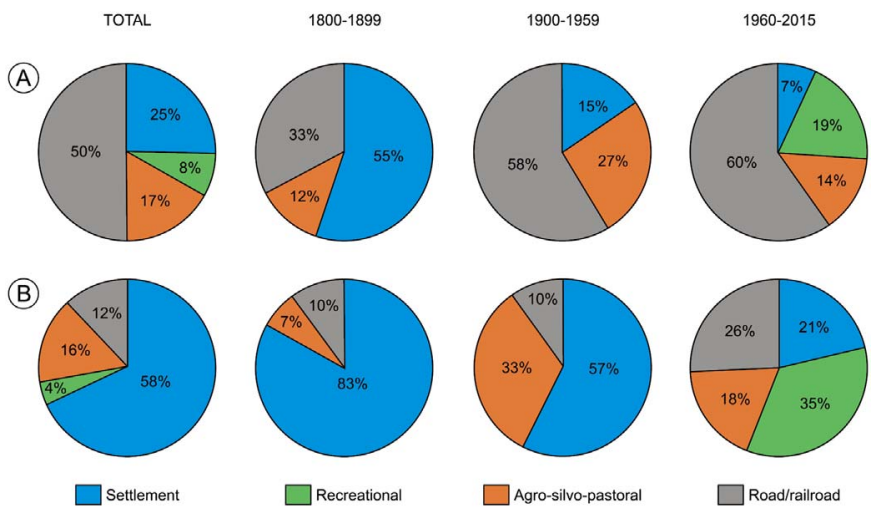

Fig. 8. (A) Percentage of avalanches and (B) percentage of total damage index according to the land use of the affected areas and periods.

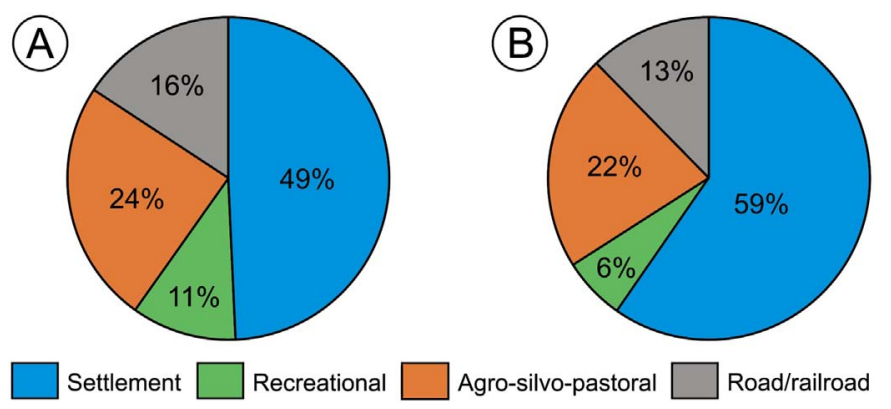

Fig. 9. (A) Percentage of personal victims (killed and injured) and (B) percentage of fatalities according to the land use of the affected areas.

\section{Table 3}

Personal victims and fatalities per avalanche, and ratio of survival according to the landuse of the affected area.

\begin{tabular}{llll}
\hline Land-use & Personal victims & Fatalities & Ratio of survivals \\
\hline Settlement & 2.3 & 1.5 & $32 \%$ \\
Agro-silvo-pastoral & 1.7 & 0.9 & $49 \%$ \\
Recreational & 1.6 & 0.5 & $67 \%$ \\
Road/rairoad & 0.4 & 0.2 & $56 \%$ \\
\hline
\end{tabular}

and early 21st centuries. This may be due to the fact that natural avalanche activity has not significantly varied over time, as it is the case of the Alps (Schneebeli et al., 1997; Laternser and Schneebeli, 2002). However, contrary to the Alps, in the Asturian Massif, there has been an absence of mitigation measures.

Although the number of damaging avalanches in the Asturian Massif has not decreased, a significant and progressive decrease is detected, both of the TD index and the damage index per avalanche (Fig. 5A). The decrease of the damages caused by snow avalanches over recent decades is a worldwide trend (United Nations, 2002). However, the distribution of the avalanche damage index, considering the land use, shows an increase between the first and the second stage (Fig.7). Therefore, the progressive decline observed in the global patern is only explained by the change detected in land uses: while in the first stage $55 \%$ of damaging avalanches occurred in settlements (the land use in which the average damage was the highest), in the second stage this type only accounted for $15 \%$ of the events (Fig.8A), prompting the other categories to gain relative importance, causing the decline of the TD index.

Settlements concentrated most of the victims caused by avalanches (with the lowest survival rate), the most extreme events and most of the TD index, namely during the stage 1800-1899 (which produced almost half of the total victims). Specifically, the last third of the 19th century recorded the highest number of extreme avalanches with the highest number of injured and deaths. This exceptionally damaging period corresponds to the last decades of the Little Ice Age, an interval between 1570 and 1900 when temperatures fell significantly below the 1961-1990 mean in many mountain regions of the Northern Hemisphere (Matthews and Briffa, 2005). During the second half of the 19th century, there are widespread evidence in historical Iberian sources of colder temperatures together with intensification of climate variability and extreme events (Alvarez-Vazquez, 1986; Barriendos and Martin-Vide, 1998).

The stage 1960-2015 (in which the number of avalanches that affected settlements was substantially lower), concentrated only $20 \%$ of the victims and there was a significant increase of the survival rate (66\%). Even taking into account the possibility that the survival rate of the past has been affected by a sub-register, as it happens in other studies on natural hazards inferred from historical documents (Podolskiy et al., 2014), in this study, avalanches in settlements show the lowest survival rate recorded in comparison to the rest of land uses. This explains the high damages recorded in southern aspects since, in the Asturian Massif, during the Middle Ages settlements used to be placed close to the land suitable for cultivation, preferably with orientations S, SE and SW (García-Fernández, 1980). Therefore, the evolution of damage in settlements determines the long-term decrease of the damages from the first stage to the last.

\subsection{Changing spatial patterns of avalanche damage}

The damage decline over time has been widespread throughout the Asturian Massif, though the decrease has been more pronounced in the western sector. In turn, in all areas most of the avalanches affecting settlements occurred during the first stage (1800-1899). Personal and material damage started increasing (not in general but in relative terms, 

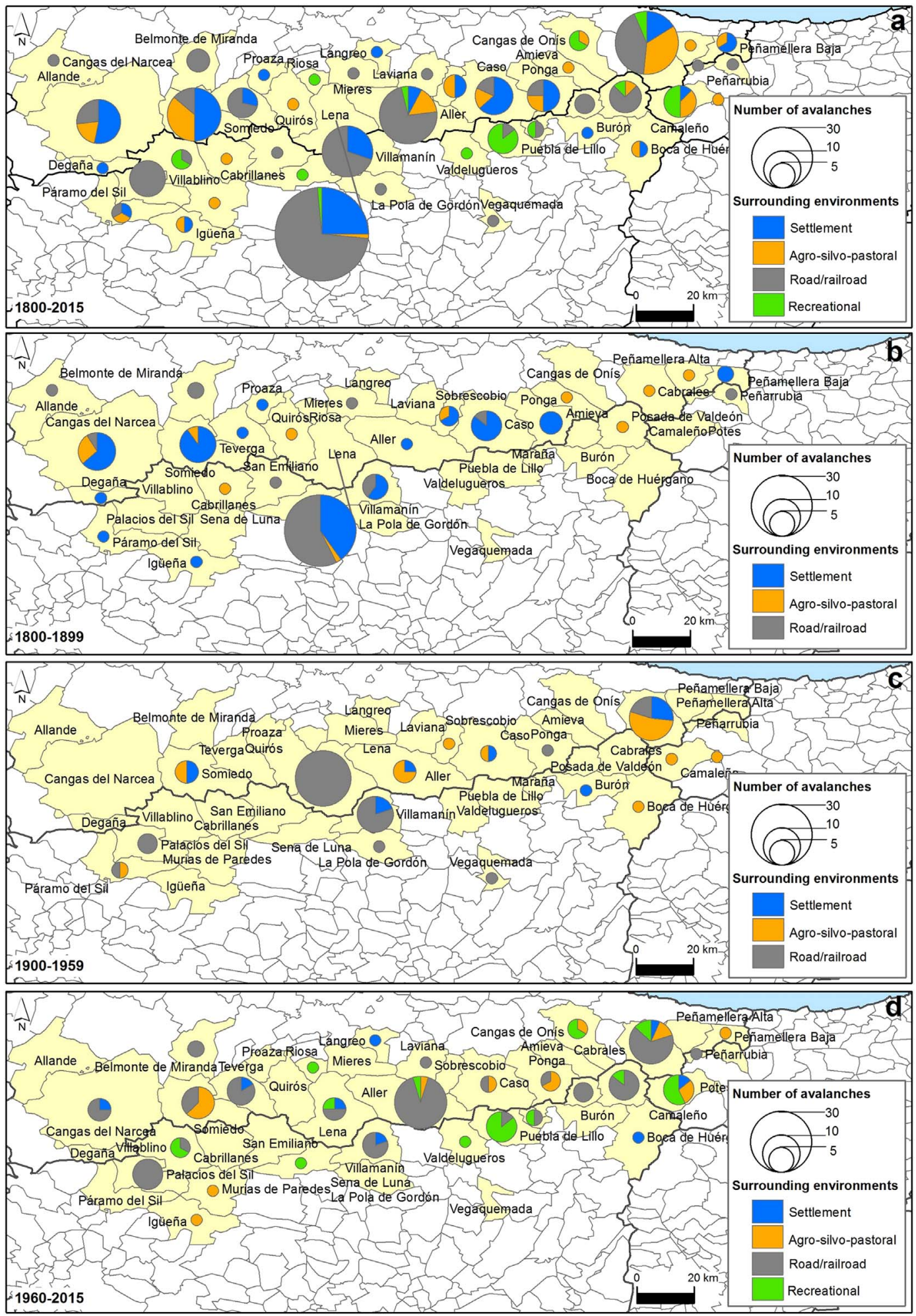

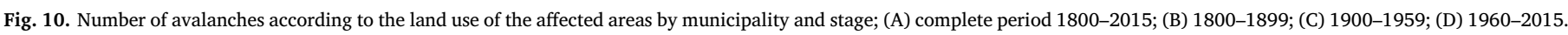

compared to the other sectors) in the eastern side of the massif between 1900 and 1959, and increased further during the third stage, when the central area of the massif remained stable. During the third stage, the recreational typology increased significantly, especially in the eastern sector. The Picos de Europa National Park (containing the Montaña de Covadonga area, the oldest protected environment in Spain) is one of the most appreciated areas by mountaineers, especially since the 1960s (Suárez et al., 2005). This region includes a large part of the eastern sector of the Massif and concentrates the highest peaks and steeper slopes of the Cantabrian Mountains, with the highest snow accumulation rates (Muñoz-Jiménez, 1982). These conditions determine a high natural avalanche activity in a highly frequented area by mountaineers, which explains the increased occurrence of avalanches related with recreational activities in this sector since the 1960s. This kind of avalanches usually causes more personal injuries than material damages, which explains why in the eastern sector the former has been 


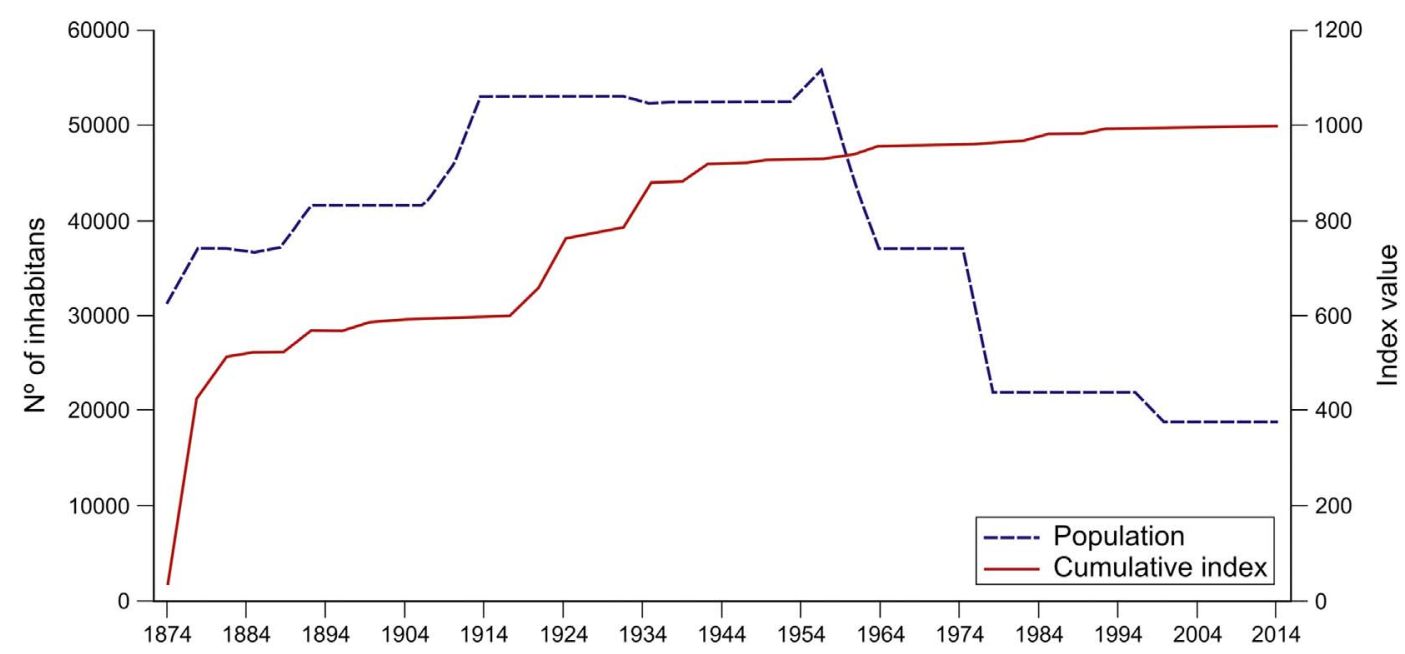

Fig. 11. Evolution of the TD cumulative index compared to population in selected Asturian Massif municipalities from 1874 to 2014.

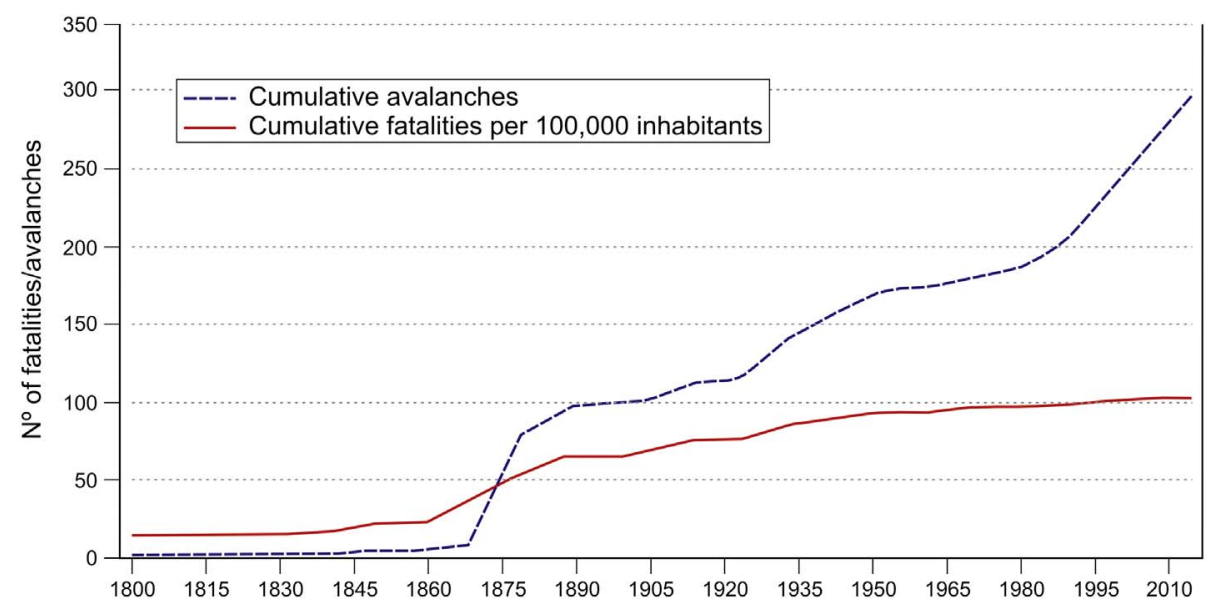

Fig. 12. Evolution of the cumulative number of avalanches compared to the number of killed per 100,000 inhabitants.

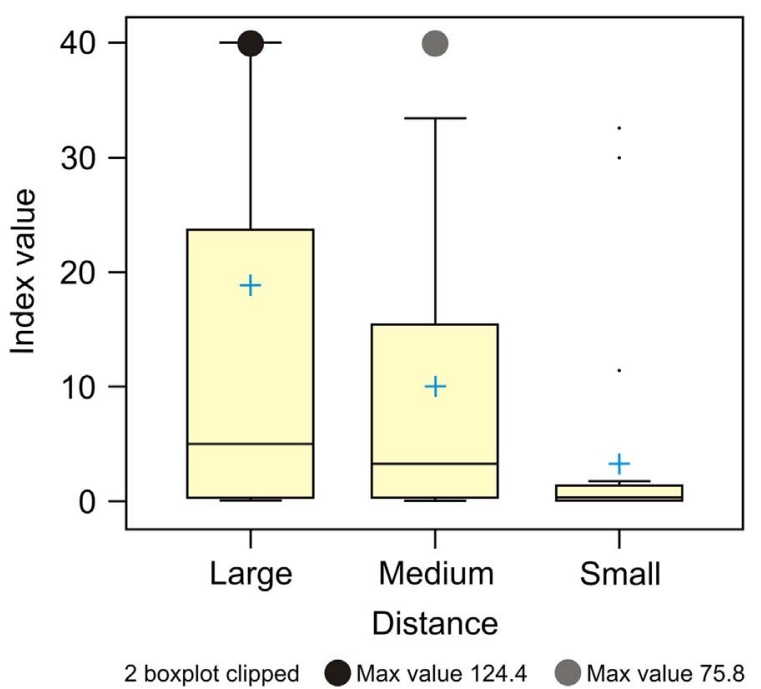

Fig. 13. Distribution of TD index according to the travelled distance until impacting the target of the 126 avalanches with a well-documented avalanche path.

higher than material damage during the last stage. On the other hand, avalanches affecting mountain climbers explain the concentration of AT avalanches, as well as the concentration of triggering areas in which vegetation is sparse, that have been active in the last stage (1960-2015).
In the central sector of the massif, there are three of the most transitated mountain passes and three of the four ski resorts existing in the Asturian Massif. This enhances the potential of damage, mainly through avalanches affecting roads, although an over-representation of damage may exist in this sector, due to its greater socio-economic interest (Raška et al., 2014). By contrast, the western sector does not have neither the transport infrastructure density of the central sector nor the tourist attraction of the eastern sector. Also, almost the totality of the damage caused by avalanches belonging to the agro-silvopastoral category occurred during the first two stages and affected to peripheral environments of the massif where economy was completely based on the primary sector until mid-20th century (García-Fernández, 1980). Other research examining similar study periods in regions of Australia (Irwin and Owens, 2004), North America (Hétu et al., 2011) and Eurasia (Podolskiy et al., 2014), show the same progressive reduction in the number of snow avalanches affecting settlements and work environments, and an increase of avalanches related with recreational activities during the second half of the 20th century.

\subsection{Historical and geographical background for avalanches until 1960}

The decrease in the number of avalanches affecting settlements is key for the evolution of the general damages. This decrease could have been partly driven by population fluctuations, since the Asturian mountains have been subject to a depopulation process since the mid20th century (Fernández-García, 2006; Rodríguez-Pascual, 2006). The TD index responds with a slight delay to the demographic performance. 
Table 4

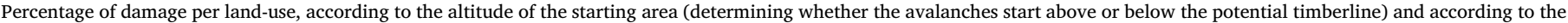
size of avalanches (based on their travelled distance).

\begin{tabular}{|c|c|c|c|c|c|c|}
\hline & \multicolumn{4}{|l|}{ \% Damage } & \multicolumn{2}{|l|}{ \% Damage } \\
\hline & \multicolumn{2}{|c|}{ Large sized avalanches } & \multicolumn{2}{|c|}{ Small-medium sized avalanches } & \multicolumn{2}{|l|}{$\begin{array}{l}\text { All sizes } \\
\text { avalanches }\end{array}$} \\
\hline & $>1600 \mathrm{~m}$ a.s.l. & $\leq 1600 \mathrm{~m}$ a.s.l. & $>1600 \mathrm{~m}$ a.s.l. & $\leq 1600 \mathrm{~m}$ a.s.l. & $\begin{array}{l}1400- \\
1600 \mathrm{~m} \text { a.s.l. }\end{array}$ & Other \\
\hline Settlements & $35 \%$ & $4 \%$ & $6 \%$ & $55 \%$ & $28 \%$ & $72 \%$ \\
\hline Road/railroad & $56 \%$ & $3 \%$ & $10 \%$ & $31 \%$ & $4 \%$ & $96 \%$ \\
\hline Agro-silvo-pastoral & $64 \%$ & $0 \%$ & $12 \%$ & $24 \%$ & $13 \%$ & $87 \%$ \\
\hline Recreational & $31 \%$ & $0 \%$ & $49 \%$ & $20 \%$ & $0 \%$ & $100 \%$ \\
\hline
\end{tabular}

However, the fact that the number of fatalities decreases regardless of population decrease (Fig.12), even when we do not dispose of data about current floating population (what would reinforce our conclusion at this regard), suggests that other historical factors (not directly but indirectly related to population dynamics) have played a more critical role.

Interestingly, $63 \%$ of the recorded avalanches occurred below the potential timberline. This must be framed with the fact that the dense forest stabilizes snow cover and limits avalanches (Gubler and Rychetnik, 1991; Newesely et al., 2000; Feistl et al., 2014). This type of avalanches was responsible for $53 \%$ of total damage between 1800 and 2015, although only $8 \%$ occurred after 1960. Consequently, changes in vegetation cover must be taken into account in order to interpret this spatio-temporal pattern. Until the mid-20th century, grazing was very intense in the Cantabrian Mountains (GarcíaFernández, 1980; Rodríguez-Pascual, 2006). Pastures induced a lowering of the timberline and developed even in steep slopes close to villages, forest covered only about a quarter of the potential forest area and tree-felling was frequent even in the remaining forest (GarcíaFernández, 1980). Besides, since the early 18th century the northern mountains of the Iberian Peninsula showed population growth peaking in late-19th century (Anglada et al., 1980). In this context of rising demographic pressure, the disentailment process was initiated by a number of liberal laws from 1812, promoting the sale of public forests to private sector that was free for tree-felling, both for grazing, agriculture, and for industrial purposes (Martí, 2003). This promoted the most widespread deforestation in Spanish history, which extended until the end of the 19th century (Bauer, 1980). Although large areas were excluded from sale in the northern slopes of the massif, privatization in mountainous areas was more intense since 1860 s, because the Catalogue of Public Utility Woodland enacted strict requirements to exclude from sale public mountain forests, requirements remaining until the late 19th century (Fernández-García, 2006). Also, the onset of mining activities in the region since the 1850s demanded large quantities of native wood, exceeding $200,000 \mathrm{~m}^{3}$ per year in the 1910s (Manuel et al., 2003) and causing extended deforestation (Pérez-González, 1980).

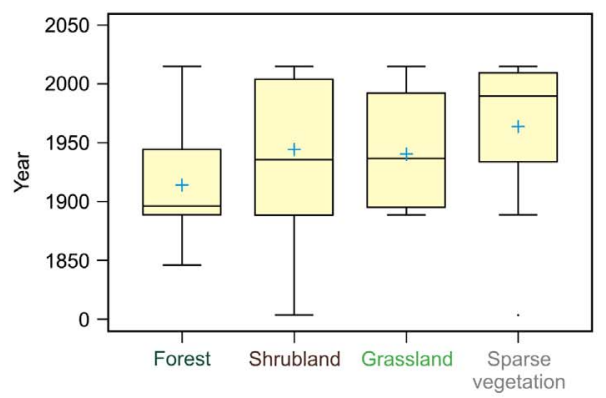

Other authors have linked deforestation as a result of increased population pressure and industrial activities, with increasing avalanches in Eurasia (Podolskiy et al., 2014) and North America (Hétu et al., 2015). One of the most heavily deforested areas in the Asturian Massif was the Western sector, which concentrated the largest oak forests. Oak was the less excluded species with successive disentailment laws, and it had a great interest for mining roof support (Sendín, 1996; Manuel et al., 2003). In Asturias, oak forests owned by the state were almost entirely privatized during this period (Martí, 2003). Sessile oak (Quercus petraea), which grows in the highest areas of the massif, had been traditionally protected by the inhabitants of the highest lands, who considered their presence an effective tool against avalanches (Lastra, 2002). In fact, dense oak forests meet the requirements to be considered protective forest as they are irregular and pluri-specific forests in which young and old specimen coexist (Gubler and Rychetnik, 1991), allowing the proliferation of saplings in lower stratum as they are open forests. Hence, tree-felling in the forests of the Western sector, especially in the great oak forest, explains concentration of damages there, especially during the late 19th century and, once tree-felling and grazing started declining, the decrease of damage was remarkable. In addition, we must take into account that oaks tend to preferentially be on south-facing slopes, which are generally the most heavily affected by human action on the Cantabrian Mountain (García et al., 2005), a fact that fits with a higher concentration of damage in south orientations.

\subsection{Recent environmental changes driving avalanche dynamics}

From the mid-20th century, the Spanish State conducted massive reforestation efforts with fast growing forest species, and the use of native trees from mountainous areas of the massif decreased, being replaced by species such as Eucalyptus globulus and Pinus pinaster (Morales, 1982). At the same time, mining activities started to decline (Pérez-González, 1980), so the demand for native wood (and therefore also deforestation) decreased markedly. Oak forests were reforested as well, multiplying their surfaces by four (Manuel et al., 2003).

An important factor contributing to reduce avalanche damage, especially in settlements, was the abandonment of the traditional

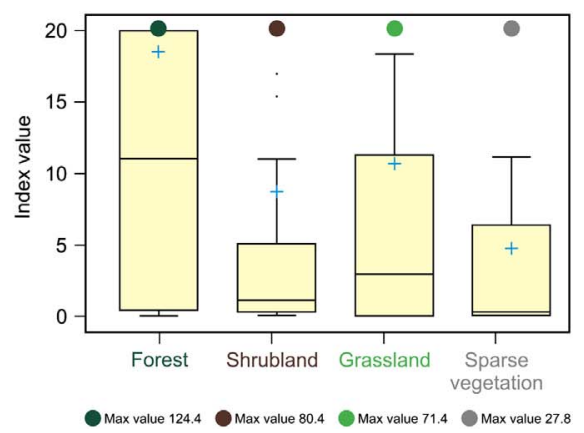

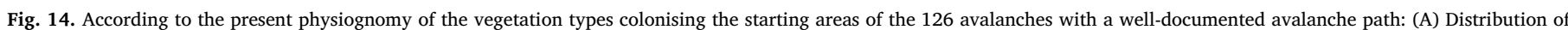
years with damaging avalanches, and (B) distribution of TD index. 

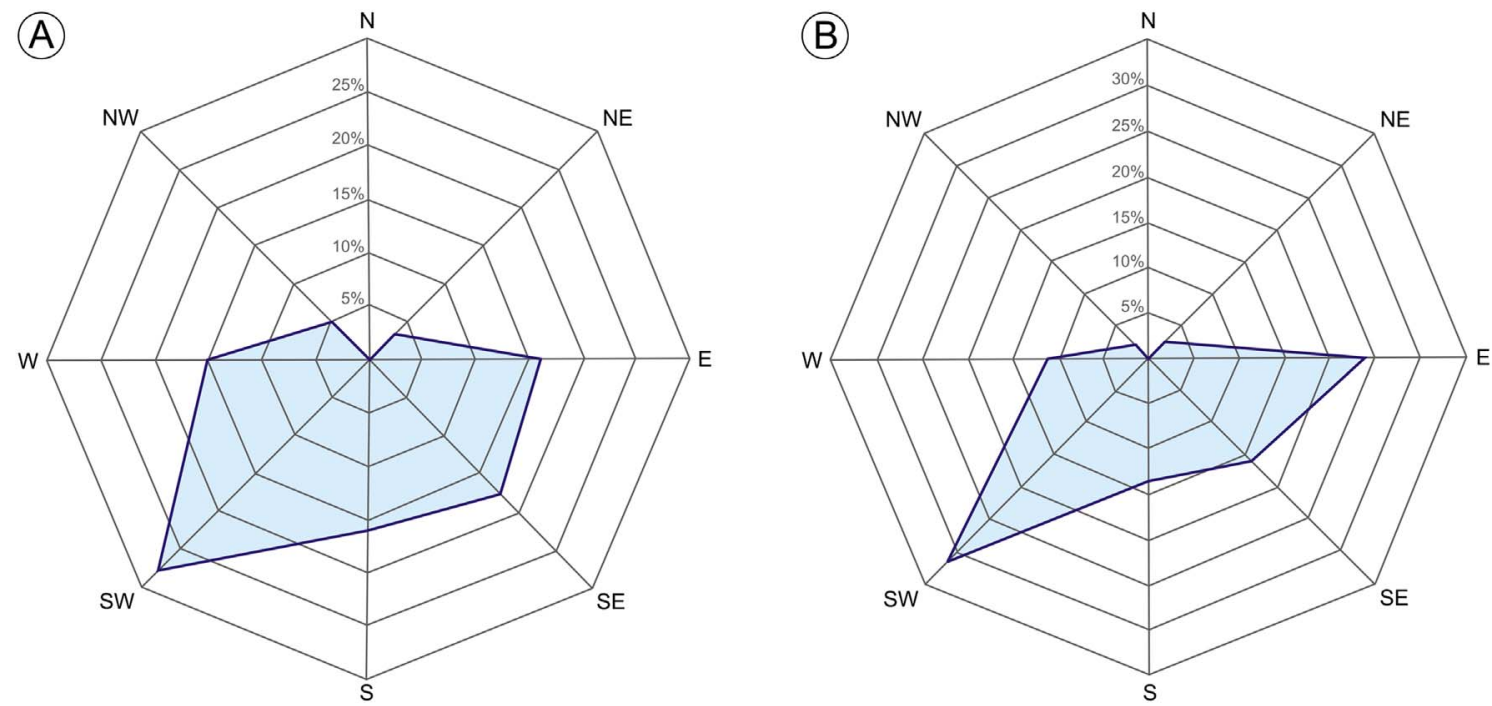

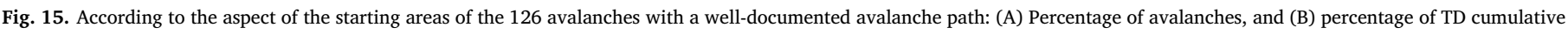
index.

management system and subsequent land-use changes in mountain environments. Since the mid-20th century, there has been a regeneration of natural vegetation due to the decrease of the importance of farming activities; this is a process that can be observed in mountain environments of many developed countries of Europe, America and Asia (Baudry and Bunce, 1991; Rudel et al., 2000; Piussi, 2000; Müller and Zeller, 2002; Gellrich et al., 2007; Cramer et al., 2008). In the Iberian Peninsula, this process has been mainly examined in the Pyrenees, where there was a progressive land marginalization because of the decrease of stocking rate, and grazing focused on flat environments located closer to the villages (Lasanta and Ruiz, 1990). This led to a vegetation colonization process which last stage is the passive reforestation of formerly grazed areas (Lasanta, 1990). In the Asturian Massif, this phenomenon has been equally intense (Zuazúa et al., 1985; Cascos, 2011; Álvarez-Martínez et al., 2013). Here, there was an abandonment of the most distant farm lands and pastures (Rodríguez-
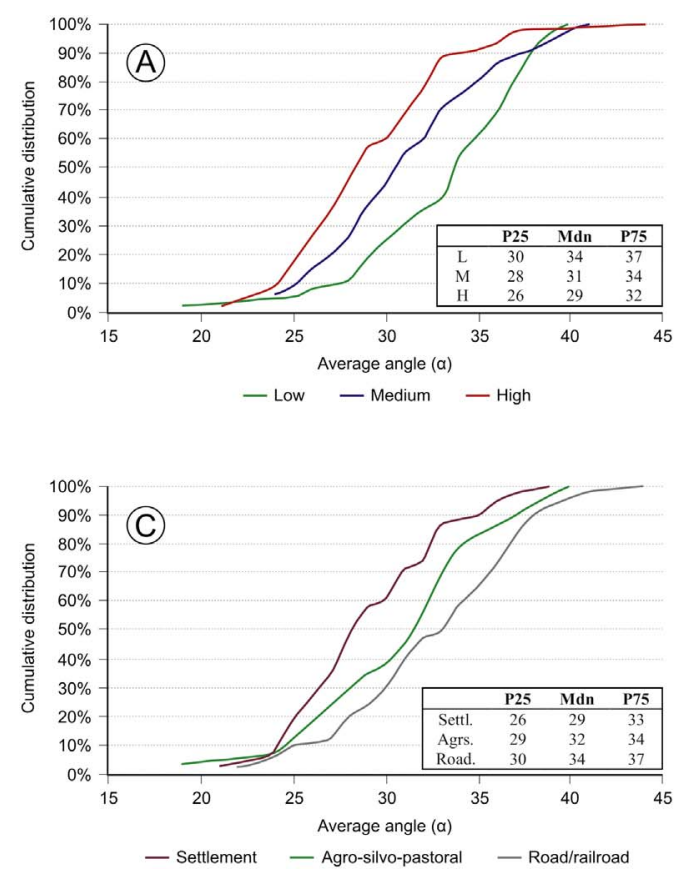

Pascual, 2006) that resulted in the recovery of the forest. In the first decade of 21st century, the main mountain municipalities of the massif had increased their forested area by $15 \%$ (on average) with respect to the 1960s (Bengoa, 2011). In this period, there has been a significant expansion and densification of the forest at higher elevations (García de Celis et al., 2004).

Apart from the lower demographic pressure, another factor to be taken into account is the progressive specialisation in bovine breeding, which intensified after 1940 (Fernández-García, 2006). Since then, most of the livestock consisted of foreign cattle breeds for milking, unfit for grazing steep areas (Ortega-Valcárcel, 1989). Shepherds almost disappeared together with goat flocks, which were expelled from many areas because they were considered "enemies of the forest" (RodríguezPascual, 2006). The decrease of goat grazing in steeper slopes, where they usually grazed exerting an important biomass control (Osoro et al., 2000), has promoted the extension of protective forest (Gubler and
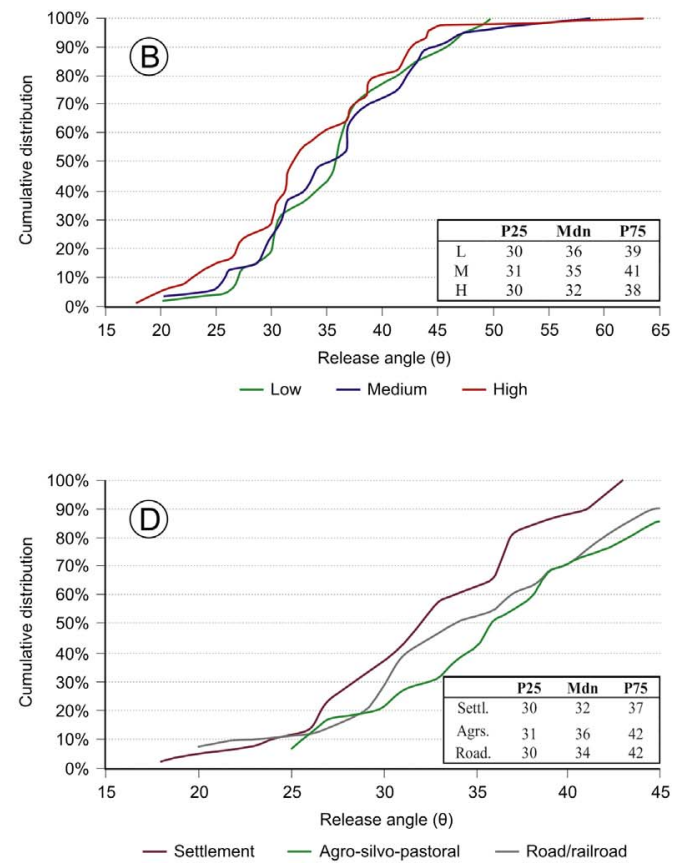

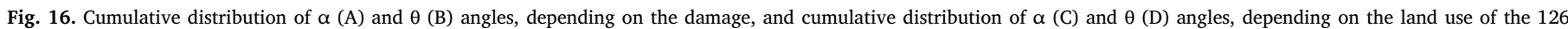
avalanches with a well-documented avalanche path. 

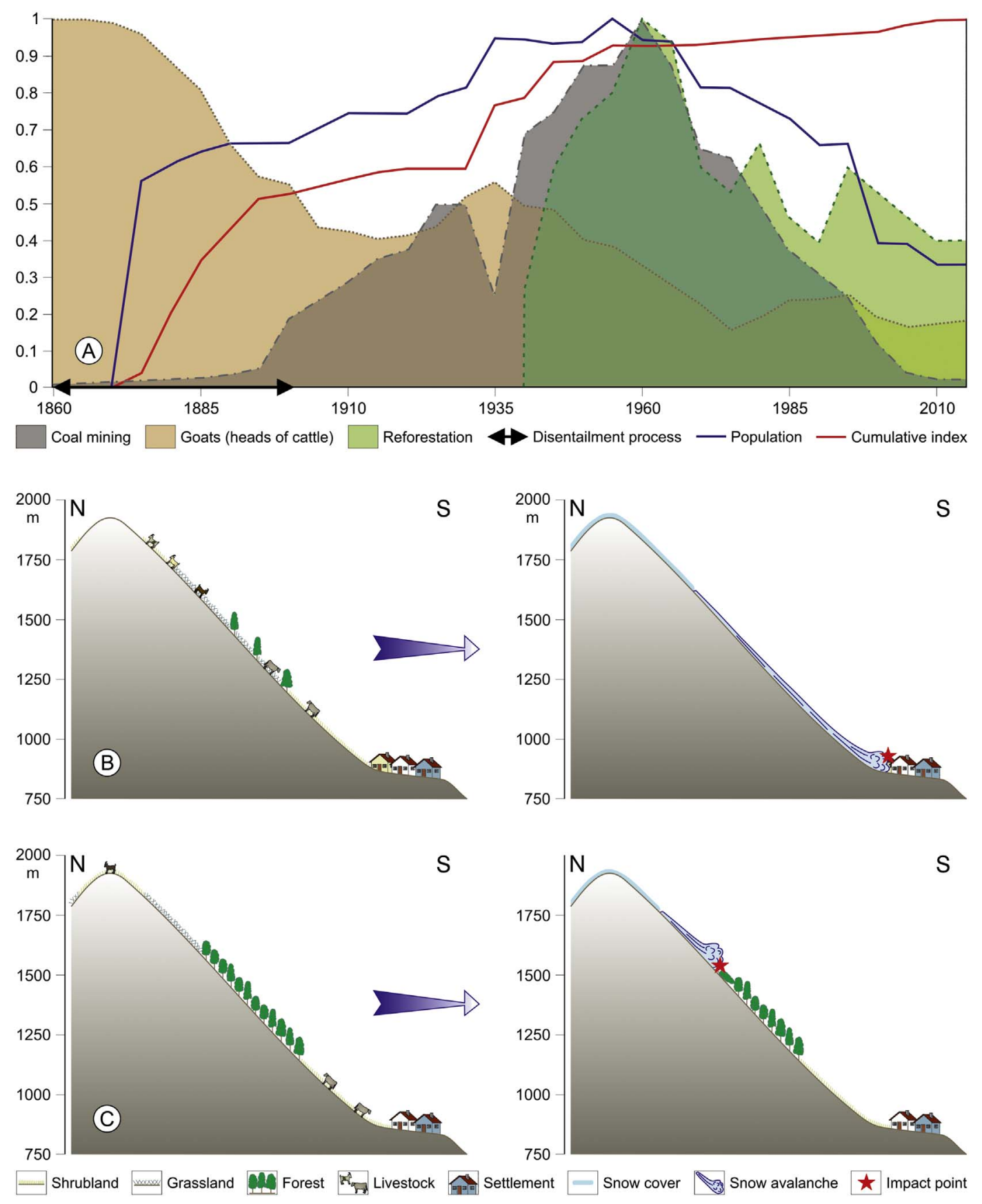

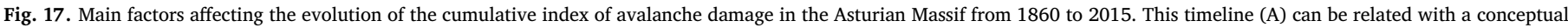

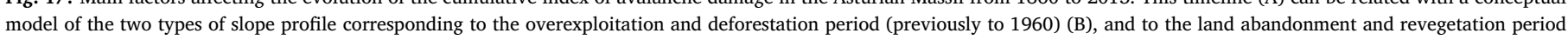
(after 1960) (C), respectively.

Rychetnik, 1991; Bebi et al., 2001). These social processes are displayed in a timeline and related with the evolution of the damage index (Fig. 17).

\subsection{Vegetation recovery and interactions between social and natural systems}

Once grazing is abandoned and deforestation decreases, the avalanche activity depends mainly on the resilience of the vegetation (Germain et al., 2005). In this sense, land-use intensity and time-lag following the abandonment will be of crucial importance, as well as the frequency and magnitude of avalanches, since they can constrain the growth of trees (Tasser et al., 2007). In the 126 avalanches with a welldocumented avalanche path, the damage increased as the average slope gradient was lower; the most damaging avalanches (specifically those affecting settlements, which are in areas with lower slope angles) were released on moderated slopes, in which avalanches are not frequent, allowing for a more successful succession of vegetation. This is confirmed by the fact that the forests currently cover the majority of the most severely affected areas in the past, namely before 1950 .

Another important aspect to consider is the lithology. While the limestones of the eastern sector of the massif do not allow for the development of deep soils, the bedrock of the western sector composed of quartzite, sandstone and slates favours the formation of welldeveloped soils and enhances a faster re-vegetation process. Spontaneous reforestation processes have been especially active between 1400 and $1600 \mathrm{~m}$ a.s.l., an elevation belt intensely used for grazing activities (García-Fernández, 1980; Ruiz-Fernández et al., 
2008) where several avalanches occurred causing significant damage to settlements.

Other factors, besides forest expansion, could explain the decrease of damage since the braking effect of the forest on avalanche propagation is very efficient in the case of small-to medium-sized avalanches released below the timberline (Teich et al., 2012), though it is limited for large avalanches starting above it (Bartelt and Stöckli, 2001; Margreth, 2004; Teich et al., 2012; Feistl et al., 2014). Such other factors may be the abandonment or under occupation of settlements affected by these avalanches. Therefore, the decrease in damage caused by large avalanches that started above the timberline cannot be explained only by forest growth.

Apart from the protective effect produced by the presence of the forest, revegetation may also has negative effects, since it increases the potential for fires (Pausas and Keeley, 2009), decreases the landscape heterogeneity and even the biodiversity (Hunziker, 1995; Lasanta et al., 2011), although this last point is highly debated at the moment (BlancoFontao et al., 2011). Considering all of the above, at present, efforts are being made to counteract this process (Lasanta et al., 2011). Some authors have noted that grazing activities can diminish the protective capacity of the forest (Gubler and Rychetnik, 1991), although in recent years grazed forests have been also used to stop avalanches (Bebi et al., 2001; Mayer and Stöckli, 2005). In addition, frequent human-induced fires conducted in order to control revegetation can cause wildfires, which in turn can reactivate avalanches near settlements and roads (Santos-González et al., 2010). Therefore, well-managed and controlled grazing can be compatible with the maintenance of the protective effect of the forest and can be a useful tool to prevent both fires and avalanches.

\section{Conclusions}

From 1800 to 2015, the number of damaging avalanches in the Asturian Massif has not decreased, but there has been a progressive decrease in damage. The decline of damage per avalanche is explained by changes in land use of affected areas from settlements to recreational uses and transportation networks, in which damages are less severe. This phenomenon explains the spatial behaviour of damages.

The transformation of a traditional land-management system based on overexploitation into a system based on land abandonment and marginalization, has been the main factor influencing the evolution of damage over the last fifty years, by means of passive reforestation. Before this, massive felling and clearing had led forests to lose their function as protective structures against avalanches; this process was particularly intense during the late 19th and early 20th centuries because of demographic growth, disentailment laws and emerging coal mining. This explains the rise of damage during these decades, namely because of avalanches affecting settlements, which released mostly below the potential timberline. Since the mid-20th century, population decline and reduction of livestock activity, together with a sharp drop in demand of native wood, allowed the recovery of vegetation, which experienced the consecutive stages of succession resulting in dense, protective forests. Forest succession was more effective in less steep areas, which were also the areas where the most damaging avalanches, affecting settlements, occurred.

The deceleration of a more intense deforestation, in parallel to a more successful process of natural vegetation recovery, favoured by the existence of deeper soils, resulted in a sharper and earlier decline of damage in the Western sector of the Asturian Massif. Since the 1960s, the damage per avalanche started an evident decrease in the whole territory, but the Eastern sector gained relative importance by absorbing the majority of damage caused by avalanches related to recreation and sports in mountain environments, and the relative importance of the Central sector remained stable since it contained most of the infrastructures.

The effects of the revegetation process are currently being highly discussed by the scientific community. The results of this study highlight one of its possible positive consequences: the reduction of avalanche damage. Nevertheless, taking into account other effects of this process (which may increase the potential for fires and has been widely considered negative from the cultural point of view), planning is imperative. Plans must be carried out to preserve protective forests, but these actions can be combined with controlled grazing in forests assessing potential release areas, so we can get all the advantages of those clearing actions without sacrificing the existence of the protective effects of the forest against snow avalanches.

\section{Acknowledgements}

This research was supported by the FPU program of Ministerio de Educación, Cultura y Deporte under doctoral fellowship of Cristina García-Hernández [grant number MECD-15-FPU14/01279]. Susana Pereira was funded by the project FORLAND - Hydrogeomorphologic risk in Portugal: driving forces and application for land use planning [grant number PTDC/ATPGEO/1660/2014], Fundação para a Ciência e a Tecnologia (FCT).

\section{References}

Alexander, D., 1996. The health effects of earthquakes in the mid-1990s. Disasters 20, $231-236$.

Álvarez-Martínez, J., Gómez-Villar, A., Lasanta, T., 2013. The use of goats grazing to restore pastures invaded by shrubs and avoid desertification: a preliminary case study in the Spanish Cantabrian Mountains. Land Degrad. Dev. 27, 3-13.

Alvarez-Vazquez, J.A., 1986. Drought and rainy periods in the province of Zamora in the 17th, 18th and 19th centuries. In: Lopez-Vera, F. (Ed.), Quaternary Climate in Western Mediterranean. Universidad Autonoma, Madrid, pp. 221-235.

Anglada, S., Balcells, E., Creus, J., García-Ruiz, J.M., Martí, C.E., Puigdefábregas, J., 1980. La vida rural en la montaña española: orientaciones para su promoción. Consejo Superior de Investigaciones Científicas. Universidad de Zaragoza, Jaca.

Barriendos, M., Martin-Vide, J., 1998. Secular climatic oscillations as indicated by catastrophic floods in the Spanish Mediterranean coastal area (14th-19th centuries). Clim. Chang. 38 (4), 473-491.

Bartelt, P., Stöckli, V., 2001. The influence of tree and branch fracture, overturning and debris entrainment on snow avalanche flow. Ann. Glaciol. 32, 209-216.

Baudry, J., Bunce, R.G.H., 1991. Land Abandonment and Its Role in Conservation. Options Méditerranéennes, série A: Séminaires Méditerranéennes nº 15 CIHEAM, Zaragoza.

Bauer, E., 1980. Los montes de España en la historia. Ministerio de Agricultura, Madrid.

Bebi, P., Kienast, F., Schönenberger, W., 2001. Assessing structures in mountain forests as a basis for investigating the forests' dynamics and protective function. For. Ecol Manag. 145 (1), 3-14.

Below, R., Wirtz, A., Guha-Sapir, D., 2009. Disaster category classification and peril terminology for operational purposes. In: Common Accord. Centre for Research on the Epidemiology of Disasters and Munich Reinsurance Company. CRED Working Paper. CRED, Brussels, Belgium 264.

Bengoa, J. (2011). Cambios en el paisaje en la Cordillera Cantábrica (Asturias, Cantabria y Castilla y León) en los últimos 40 años: comparativa de superficies arboladas a partir del mapa forestal. In: Ezquerra, F.J., Rey, E. (Coords.), La evolución del paisaje vegetal y el uso del fuego en la Cordillera Cantábrica, Juan de Castilla y León, Valladolid, 185-198.

Blanco-Fontao, B., Quevedo, M., Obeso, J.R., 2011. Abandonment of traditional uses in mountain areas: typological thinking versus hard data in the Cantabrian Mountains (NW Spain). Biodivers. Conserv. 20 (5), 1133-1140.

Cascos, C., 2011. La simplificación y la uniformidad crecientes en los paisajes ganaderos de la montaña húmeda de Castilla y León: el ejemplo de Babia y Luna. Polígonos. Revista de Geografía 21, 149-178.

Castañón, J.C., 1984. Sobre el modelado originado por los aludes de nieve en el Prau del Albo (Alto Huerna, Asturias). Ería 6, 106-112.

Cramer, V.A., Hobbs, R.J., Standish, R.J., 2008. What's new about old fields? Land abandonment and ecosystem assembly. Trends Ecol. Evol. 23 (2), 104-112.

European Environment Agency, 2010. Mapping the Impacts of Natural Hazards and Technological Accidents in Europe. An Overview of the Last Decade. EEA, Copenhagen.

Feistl, T., Bebi, P., Teich, M., Bühler, Y., Christen, M., Thuro, K., Bartelt, P., 2014. Observations and modeling of the braking effect of forests on small and medium avalanches. J. Glaciol. 60 (219), 124-138.

Fekete, A., 2009. Validation of a social vulnerability index in context to river-floods in Germany. Nat. Hazards Earth Syst. Sci. 9 (2), 393-403.

Fernández-Cañadas, J.A., Palomo, M., Pantoja, L., 2015. Delimitación espacial de las zonas probables de salida de aludes en el macizo de Peñalara mediante el uso de SIG. Espacio Tiempo y Forma Serie VI, Geografía 6-7, 73-94.

Fernández-García, F., 2006. La quiebra del modelo histórico de organización de la Montaña Cantábrica. In: Delgado-Viñas, C. (Ed.), La Montaña Cantábrica, una montaña viva; Cátedra Cantabria. Parlamento de Cantabria y Universidad de 
Cantabria, Santander, pp. 79-98.

Fuchs, S., Bründl, M., Stötter, J., 2004. Development of avalanche risk between 1950 and 2000 in the municipality of Davos, Switzerland. Nat. Hazards Earth Syst. Sci. 4 (2), 263-275.

Fuchs, S., Keiler, M., Zischg, A., Bründl, M., 2005. The long term development of avalanche risk in settlements considering the temporal variability of damage potential. Nat. Hazards Earth Syst. Sci. 5, 893-901.

Furdada, G., Martí, G., Oller, P., García, C., Mases, M., Vilaplana, J.M., 1995. Avalanche mapping and related G.I.S. applications in the Catalan Pyrenees. Surv. Geophys. 16, 681-693.

García de Celis, A.J., Guerra Velasco, J.C., Martínez Fernández, L.C., 2004. Los abedulares de la Omaña Alta (León): notas sobre dinámica vegetal y cambios en el aprovechamiento de los montes. Boletín de la Asociación de Geógrafos Españoles 38, 245-260.

García, D., Quevedo, M., Obeso, J.R., Abajo, A., 2005. Fragmentation patterns and protection of montane forest in the Cantabrian range (NW Spain). For. Ecol. Manag. 208 (1), 29-43.

García-Fernández, J., 1980. Sociedad y organización tradicional del espacio en Asturias. Silverio Cañada, Gijón.

García-Hernández, C., Ruiz-Fernández, J., Sánchez de Posada, C., Poblete, M.A., 2014. El impacto del episodio avalanchoso de 1888 en el Macizo Asturiano, a través de la prensa. In: Gómez-Ortiz, A., Salvador, F., Oliva, M., Salvá, M. (Eds.), Avances, métodos y técnicas en el estudio del periglaciarismo. Universidade de Barcelona, Barcelona, pp. 55-64.

Geertsema, M., Schwab, J.W., Blais-Stevens, A., Sakals, M.E., 2009. Landslides impacting linear infrastructure in west central British Columbia. Nat. Hazards 48 (1), 59-72.

Gellrich, M., Baur, P., Koch, B., Zimmermann, N.E., 2007. Agricultural land abandonment and natural forest re-growth in the Swiss mountains: a spatially explicit economic analysis. Agric. Ecosyst. Environ. 118, 93-108.

Germain, D., Filion, L., Hétu, B., 2005. Snow avalanche activity after fire and logging disturbances, northern Gaspe Peninsula, Quebec, Canada. Can. J. Earth Sci. 42, 2103-2116.

Gubler, H., Rychetnik, J., 1991. Effects of forests near the timberline on avalanche formation. In: Snow, Hidrology and Forest in High Alpine Areas, Proceedings of the Vienna Symposium, IAHS. 205. pp. 19-37.

Hétu, B., Brown, K., Germain, D., 2011. Les victimes d'avalanche au Québec entre 1825 et 2009. Can. Geogr. 55 (3), 273-287.

Hétu, B., Fortin, G., Brown, K., 2015. Climat hivernal, aménagement du territoire et dynamique des avalanches au Québec méridional: une analyse à partir des accidents connus depuis 1825. Can. J. Earth Sci. 52 (5), 307-321.

Hunziker, M., 1995. The reforestation in abandoned agricultural lands: perception and aesthetical assessment by local and tourists. Landsc. Urban Plan. 31, 399-410.

IPCC, 2012. In: Field, C.B., Barros, V., Stocker, T.F., Dahe, Q. (Eds.), Managing the Risks of Extreme Events and Disasters to Advance Climate Change Adaptation, Special Report of the Intergovernemental Painel on Climate Change. Cambridge University Press, Cambridge.

Irwin, D., Owens, I., 2004. A history of avalanche accidents in Aotearoa, New Zealand. In: Proceedings of the International Snow Science Workshop. Jackson Hole, WY, pp. 484-491.

Johannesson, T., Arnalds, T., 2001. Accidents and economic damage due to snow avalanche and landslide in Iceland. Jökull 50, 81-94.

Julián, A., Chueca, J., 1999. Cartografía de zonas probables de aludes en el valle de Ordesa (Pirineo aragonés). Geographicalia 37, 73-86.

Julivert, M., 1983. La estructura de la Zona Cantábrica. Geología de España. In: Libro jubilar a J. Mª . Ríos. IGME, Madrid.

Keiler, M., Zischg, A., Fuchs, S., Hama, M., Stötter, J., 2005. Avalanche related damage potential - changes of persons and mobile values since the mid-twentieth century, case study Galtür. Nat. Hazards Earth Syst. Sci. 5, 49-58.

Kienholz, H., 1978. Maps of geomorphology and natural hazards of Grindelwald, Switzerland: scale 1: 10,000. Arct. Alp. Res. 10 (2), 169-184.

Lasanta, T., 1990. Diversidad de usos e integración espacial en la gestión tradicional del territorio en las montañas de Europa occidental. In: García-Ruiz, J.M. (Ed.), Geoecología de las áreas de montaña. Geoforma, Logroño, pp. 235-266.

Lasanta, T., Ruiz, P., 1990. Especialización productiva y desarticulación espacial en la gestión reciente del territorio en las montañas de Europa occidental. In: García-Ruiz, J.M. (Ed.), Geoecología de las áreas de montaña. Geoforma, Logroño, pp. 267-295.

Lasanta, T., Vicente-Serrano, S.M., Arnáez, J., 2011. La revegetación en áreas de montaña. ¿Dejar hacer o intervenir en el territorio? Geographicalia 59-60, 199-211.

Lastra, J.J., 2002. Bosques naturales de Asturias. Servicio de Publicaciones de la Universidad de Oviedo, Oviedo.

Laternser, M., Schneebeli, M., 2002. Temporal trend and spatial distribution of avalanche activity during the last 50 years in Switzerland. Nat. Hazards 27, 201-230.

Manuel, C.M., Díaz, P., Gil, L.A., 2003. Tercer inventario forestal nacional 1997-2006: La transformación histórica del paisaje forestal en Asturias. Ministerio de Medio Ambiente Dirección General de Conservación de la Naturaleza, Subdirección General de Montes, Madrid.

Margreth, S., 2004. Die Wirkung des Waldes bei Lawinen. Schutzwald und Naturgefahren. In: Forum für Wissen 2004, Birmensdorf, pp. 21-26.

Martí, F., 2003. La desamortización española. Ediciones Rialp, Madrid.

Martínez-Catalán, J., Hacar, M., Villar Alonso, P., Pérez-Estaún, A., González Lodeiro, F., 1992. Lower Paleozoic extensional tectonics in the limit between the West AsturianLeonese and Central Iberian Zones of the Variscan fold-belt in NW Spain. Geol. Rundsch. 81 (2), 545-560.

Mases, M., Vilaplana, J.M., 1991. Zonas de aludes en la Vallferrera: clasificación y riesgo geomorfológico. Pirineos 138, 39-52.

Matthews, J.A., Briffa, K.R., 2005. The 'little ice age': re-evaluation of an evolving concept. Geogr. Ann. Ser. A Phys. Geogr. 87 (1), 17-36.

Mayer, A.C., Stöckli, V., 2005. Long-term impact of cattle grazing on subalpine forest development and efficiency of snow avalanche protection. Arct. Antarct. Alp. Res. 37 (4), 521-526.

Merz, B., Kreibich, H., Thieken, A., Schmidtke, R., 2004. Estimation uncertainty of direct monetary flood damage to buildings. Nat. Hazards Earth Syst. Sci. 4 (1), 153-163.

Mileti, D., Myers, M.F., 1997. A bolder course for disaster reduction: imagining a sustainable future. Revista Geofisica 47, 41-58.

Morales, G., 1982. La explotación de los recursos forestales en Asturias. Ería 3, 35-54.

Müller, D., Zeller, M., 2002. Land use dynamics in the central highlands of Vietnam: a spatial model combining village survey data with satellite imagery interpretation. Agric. Econ. 27, 333-354.

Muñoz-Jiménez, J., 1982. Geografía Física. El relieve, el clima y las aguas. In: Quirós, F. (Ed.), Geografía de Asturias I. Ayalga, Oviedo.

Muñoz-Sobrino, C., Suarez-Perez, F.J., Nava-Fernandez, H.S., Fernandez-Casado, M.A., Gomez-Orellana, L., Rodriguez-Guitian, M.A., Fernandez-Prieto, J.A., Ramil-Rego, P., 2012. Environmental changes in the westernmost Cantabrian range during the postglacial period: the Pena Velosa (Muniellos, Asturias) pollen record. In: Environmental Changes and Human Interaction along the Western Atlantic Edge, pp. 79-94 (Associação Portuguesa para o Estudo do Quaternário Coimbra).

Muntán, E., García, C., Oller, P., Martí, G., García, A., Gutiérrez, E., 2009. Reconstructing snow avalanches in the southeastern Pyrenees. Nat. Hazards Earth Syst. Sci. 9, 1599-1612.

Newesely, C., Tasser, E., Spadinger, P., Cernusca, A., 2000. Effects of land-use changes on snow gliding processes in alpine ecosystems. Basic Appl. Ecol. 1 (1), 61-67.

Ortega-Valcárcel, J., 1989. La economía de montaña, una economía de equilibrio. Ería 19, $115-128$.

Osoro, K., Vassallo, J.M., Celaya, M.R., Martínez, A., 2000. Resultados de la interacción vegetación por manejo animal en dos comunidades vegetales naturales de la Cordillera Cantábrica. Investigación agraria. Producción y sanidad animales 15, $137-158$.

Pausas, J.G., Keeley, J.E., 2009. A burning story: the role of fire in the history of life. Bioscience 59 (7), 593-601.

Peduzzi, P., Dao, H., Herold, C., 2005. Mapping disastrous natural hazards using global datasets. Nat. Hazards 35 (2), 265-289.

Pereira, S., Ramos, A.M., Zêzere, J.L., Trigo, R.M., Vaquero, J.M., 2016. Spatial impact and triggering conditions of the exceptional hydro-geomorphological event of December 1909 in Iberia. Nat. Hazards Earth Syst. Sci. 16 (2), 371-390.

Pérez-González, R., 1980. Industria, población y desarrollo urbano en la cuenca central hullera asturiana. PhD Thesis. University of Oviedo, Oviedo.

Pfister, C., Weingartner, R., Luterbacher, J., 2006. Hydrological winter droughts over the last 450 years in the Upper Rhine basin: a methodological approach. Hydrol. Sci. J. 51, 966-985.

Piussi, P., 2000. Expansion of European mountain forests. In: Price, M.F., Butt, N. (Eds.) Forests in Sustainable Mountain Development: A State of Knowledge Report for 2000. CABI Publishing, Wallingford, UK, pp. 19-25.

Podolskiy, E.A., Izumi, K., Suchkov, V.E., Eckert, N., 2014. Physical and societal statistics for a century of snow-avalanche hazards on Sakhalin and the Kuril Islands (1910-2010). J. Glaciol. 60 (221), 409-430.

Raška, P., Zábranský, V., Dubišar, J., Kadlec, A., Hrbáčová, A., Strnad, T., 2014. Documentary proxies and interdisciplinary research on historic geomorphologic hazards: a discussion of the current state from a central European perspective. Nat. Hazards 70, 705-732.

Rodríguez-Pascual, M., 2006. Evolución de la ganadería y el paisaje en la zona meridional de la Cordillera Cantábrica. In: Delgado-Viñas, C. (Ed.), La Montaña Cantábrica, una montaña viva. Universidad de Cantabria, Santander, pp. 197-205.

Rudel, T.K., Perez-Lugo, M., Zichal, H., 2000. When fields revert to forest: development and spontaneous reforestation in post-war Puerto Rico. Prof. Geogr. 52, 386-397.

Ruiz-Fernández, J., González-Trueba, J.J., Poblete, M.A., 2008. La montaña media cabraliega. In: Ruiz-Flaño, P., Serrano, E., Poblete, M.A., Ruiz-Fernández, J. (Eds.), De Castilla al mar. La naturaleza del paisaje en la Montaña Cantábrica. Asociación de Geógrafos Españoles - Universidad de Valladolid - Universidad de Oviedo, Santander, pp. 99-124.

Ruiz-Fernández, J., Oliva, M., Cruces, A., Lopes, V., Freitas, M.C., Andrade, C., GarcíaHernández, C., López-Sáez, J.A., Geraldes, M., 2016. Environmental evolution in the Picos de Europa (Cantabrian Mountains, SW Europe) since the last glaciation. Quat. Sci. Rev. 138, 87-104.

Santos-González, J., Redondo-Vega, J.M., Gómez-Villar, A., González-Gutiérrez, R.B., 2010. Los aludes de nieve en el Alto Sil (Oeste de la Cordillera Cantábrica, España). Cuadernos de investigación geográfica 36, 7-26.

Schneebeli, M., Laternser, M., Ammann, W., 1997. Destructive snow avalanches and climate change in the Swiss Alps. Eclogae Geol. Helv. 90, 457-461.

Sendín, M.Á., 1996. Asturias en el Segundo Inventario Forestal. Ería 39-40, 131-150.

Serrano, E., Gómez-Lende, M., Pisabarro, A., 2016. Nieve y riesgo de aludes en la montaña cantábrica: el alud de Cardaño de Arriba, Alto Carrión (Palencia). Polígonos. Revista de Geografía 28, 239-264.

SLF, 2000. Der Lawinenwinter 1999. Eidenössisches Institut für Schnee-und Lawinenforschung, Davos.

Suárez, F., Herrán, M., Ruiz-Fernández, J., 2005. La adaptación del hombre a la montaña. El paisaje de Cabrales (Picos de Europa). Ería 68, 373-389.

Tasser, E., Walde, J., Tappeiner, U., Teutsch, A., Noggler, W., 2007. Land-use changes and natural reforestation in the eastern central Alps. Agric. Ecosyst. Environ. 118 (1), 115-129.

Teich, M., Bartelt, P., Grêt-Regamey, A., Bebi, P., 2012. Snow avalanches in forested terrain: influence of forest parameters, topography, and avalanche characteristics on runout distance. Arct. Antarct. Alp. Res. 44 (4), 509-519. 
Tukey, J.W., 1977. Exploratory Data Analysis. Addison-Wesley, London-Amsterdam-Don Mills-Ontario-Sydney.

UNISDR, 2009. Terminology on Disaster Risk Reduction. UN, Geneva, Switzerland.

United Nations, 2002. Living with Risk. A Global Review of Disaster Reduction Initiatives. Preliminary Version. United Nations, Geneva, Switzerland.

Vada, J.A., Frochoso, M., Vilaplana, J.M., 2012. Evaluación y cartografía del riesgo de aludes en el camino PR-PNPE 21 de acceso a la Vega de Urriellu, Picos de Europa
(Noroeste de España). Cuaternario y Geomorfología 26 (1-2), 29-47.

Wozniak, E., Marquínez, J., 2004. Evaluación de la susceptibilidad por aludes a escala regional: el caso de Asturias. In: Benito, G., Díez-Herrero, A. (Eds.), Riesgos Naturales y Antrópicos en Geomorfología. Sociedad Española de Geomorfología - Centro de Ciencias Medioambientales (CSIC), Madrid, pp. 509-518.

Zuazúa, M.T., Luis, E., Navascúes, E., 1985. Primeras etapas de la sucesión del pastizal en campos de cultivo abandonados en las tierras altas de León. Pastos 15, 9-19. 